\title{
Sources, seasonality, and trends of southeast US aerosol: an integrated analysis of surface, aircraft, and satellite observations with the GEOS-Chem chemical transport model
}

\author{
P. S. Kim ${ }^{1}$, D. J. Jacob ${ }^{1,2}$, J. A. Fisher ${ }^{3}$, K. Travis ${ }^{2}$, K. Yu², L. Zhu' ${ }^{2}$, R. M. Yantosca ${ }^{2}$, M. P. Sulprizio ${ }^{2}$, \\ J. L. Jimenez ${ }^{4,5}$, P. Campuzano-Jost ${ }^{4,5}$, K. D. Froyd ${ }^{4,6}$, J. Liao ${ }^{4,6}$, J. W. Hair ${ }^{7}$, M. A. Fenn ${ }^{8}$, C. F. Butler ${ }^{8}$, \\ N. L. Wagner ${ }^{4,6}$, T. D. Gordon ${ }^{4,6}$, A. Weltit ${ }^{4,6,9, a}$, P. O. Wennberg ${ }^{10,11}$, J. D. Crounse ${ }^{10}$, J. M. St. Clair ${ }^{10, b, c}$, A. P. Teng ${ }^{10}$, \\ D. B. Millet ${ }^{12}$, J. P. Schwarz ${ }^{6}$, M. Z. Markovic ${ }^{4,6, d}$, and A. E. Perring ${ }^{4,6}$ \\ ${ }^{1}$ Department of Earth and Planetary Sciences, Harvard University, Cambridge, MA, USA \\ ${ }^{2}$ School of Engineering and Applied Sciences, Harvard University, Cambridge, MA, USA \\ ${ }^{3}$ School of Chemistry, University of Wollongong, Wollongong, NSW, Australia \\ ${ }^{4}$ Cooperative Institute for Research in Environmental Sciences, University of Colorado Boulder, Boulder, CO, USA \\ ${ }^{5}$ Department of Chemistry and Biochemistry, University of Colorado Boulder, Boulder, CO, USA \\ ${ }^{6}$ Chemical Sciences Division, National Oceanic and Atmospheric Administration Earth System Research Laboratory, \\ Boulder, CO, USA \\ ${ }^{7}$ NASA Langley Research Center, Hampton, VA, USA \\ ${ }^{8}$ Science Systems and Applications, Inc., Hampton, VA, USA \\ ${ }^{9}$ Institute for Atmospheric and Climate Science, Swiss Federal Institute of Technology, Zurich, Switzerland \\ ${ }^{10}$ Division of Geological and Planetary Sciences, California Institute of Technology, Pasadena, CA, USA \\ ${ }^{11}$ Division of Engineering and Applied Science, California Institute of Technology, Pasadena, CA, USA \\ ${ }^{12}$ Department of Soil, Water, and Climate, University of Minnesota, Minneapolis-Saint Paul, MN, USA \\ a now at: Experimental Aerosol and Cloud Microphysics, Leibniz Institute for Tropospheric Research (TROPOS), \\ Leipzig, Germany \\ ${ }^{b}$ now at: Atmospheric Chemistry and Dynamics Laboratory, NASA Goddard Space Flight Center, Greenbelt, MD, USA \\ ${ }^{c}$ now at: Joint Center for Earth Systems Technology, University of Maryland Baltimore County, Baltimore, MD, USA \\ ${ }^{d}$ now at: Air Quality Research Division, Environment Canada, Toronto, ON, Canada
}

Correspondence to: P. S. Kim (kim68@fas.harvard.edu)

Received: 5 May 2015 - Published in Atmos. Chem. Phys. Discuss.: 1 July 2015

Revised: 3 September 2015 - Accepted: 5 September 2015 - Published: 23 September 2015

\begin{abstract}
We use an ensemble of surface (EPA CSN, IMPROVE, SEARCH, AERONET), aircraft (SEAC $\left.{ }^{4} \mathrm{RS}\right)$, and satellite (MODIS, MISR) observations over the southeast US during the summer-fall of 2013 to better understand aerosol sources in the region and the relationship between surface particulate matter (PM) and aerosol optical depth (AOD). The GEOS-Chem global chemical transport model (CTM) with $25 \times 25 \mathrm{~km}^{2}$ resolution over North America is used as a common platform to interpret measurements of different aerosol variables made at different times and locations. Sulfate and organic aerosol (OA) are the main contributors to
\end{abstract}

surface $\mathrm{PM}_{2.5}$ (mass concentration of PM finer than $2.5 \mu \mathrm{m}$ aerodynamic diameter) and AOD over the southeast US. OA is simulated successfully with a simple parameterization, assuming irreversible uptake of low-volatility products of hydrocarbon oxidation. Biogenic isoprene and monoterpenes account for $60 \%$ of $\mathrm{OA}$, anthropogenic sources for $30 \%$, and open fires for $10 \%$. $60 \%$ of total aerosol mass is in the mixed layer below $1.5 \mathrm{~km}, 25 \%$ in the cloud convective layer at $1.5-3 \mathrm{~km}$, and $15 \%$ in the free troposphere above $3 \mathrm{~km}$. This vertical profile is well captured by GEOS-Chem, arguing against a high-altitude source of OA. The extent 
of sulfate neutralization $\left(f=\left[\mathrm{NH}_{4}^{+}\right] /\left(2\left[\mathrm{SO}_{4}^{2-}\right]+\left[\mathrm{NO}_{3}^{-}\right]\right)\right.$is only $0.5-0.7 \mathrm{~mol} \mathrm{~mol}^{-1}$ in the observations, despite an excess of ammonia present, which could reflect suppression of ammonia uptake by OA. This would explain the long-term decline of ammonium aerosol in the southeast US, paralleling that of sulfate. The vertical profile of aerosol extinction over the southeast US follows closely that of aerosol mass. GEOS-Chem reproduces observed total column aerosol mass over the southeast US within $6 \%$, column aerosol extinction within $16 \%$, and space-based AOD within 8-28\% (consistently biased low). The large AOD decline observed from summer to winter is driven by sharp declines in both sulfate and OA from August to October. These declines are due to shutdowns in both biogenic emissions and UV-driven photochemistry. Surface $\mathrm{PM}_{2.5}$ shows far less summer-towinter decrease than AOD and we attribute this in part to the offsetting effect of weaker boundary layer ventilation. The SEAC4RS aircraft data demonstrate that AODs measured from space are consistent with surface $\mathrm{PM}_{2.5}$. This implies that satellites can be used reliably to infer surface $\mathrm{PM}_{2.5}$ over monthly timescales if a good CTM representation of the aerosol vertical profile is available.

\section{Introduction}

There is considerable interest in using satellite retrievals of aerosol optical depth (AOD) to map particulate matter concentrations (PM) in surface air and their impact on public health (Liu et al., 2004; Zhang et al., 2009; van Donkelaar et al., 2010, 2015; Hu et al., 2014). The relationship between PM and AOD is a function of the vertical distribution and optical properties of the aerosol. It is generally derived from a global chemical transport model (CTM) simulating the different aerosol components over the depth of the atmospheric column (van Donkelaar et al., 2012, 2013; Boys et al., 2014). Sulfate and organic matter are the dominant submicron aerosol components worldwide (Murphy et al., 2006; Zhang et al., 2007; Jimenez et al., 2009), thus it is important to evaluate the ability of CTMs to simulate their concentrations and vertical distributions. Here we use the GEOS-Chem CTM to interpret a large ensemble of aerosol chemical and optical observations from surface, aircraft, and satellite platforms during the NASA SEAC ${ }^{4}$ RS campaign in the southeast US in August-September 2013. Our objective is to better understand the relationship between PM and AOD, and the ability of CTMs to simulate it, with focus on the factors controlling sulfate and organic aerosol (OA).

The southeast US is a region of particular interest for PM air quality and for aerosol radiative forcing of climate (Goldstein et al., 2009). $\mathrm{PM}_{2.5}$ (the mass concentration of particulate matter finer than $2.5 \mu \mathrm{m}$ aerodynamic diameter, of most concern for public health) is in exceedance of the current US air quality standard, $12 \mu \mathrm{g} \mathrm{m}^{-3}$ on an annual mean basis, in several counties (http://www.epa.gov/airquality/ particlepollution/actions.html). Concentrations have been decreasing in response to regulations targeted at protecting public health (the Clean Air Act Amendments of 1990). Figure 1 shows the summertime (JJA) and wintertime (DJF) mean concentrations of aerosol components for 2003-2013 from surface monitoring stations in the southeast US managed by the US Environmental Protection Agency (US EPA, 1999). Summertime sulfate concentrations decreased by $60 \%$ over the period, while OA concentrations decreased by $40 \%$ (Hand et al., 2012b; Blanchard et al., 2013; Hidy et al., 2014). Trends in winter are much weaker. Decreasing aerosol has been linked to rapid warming in the southeast US over the past 2 decades (Leibensperger et al., 2012a, b).

The sulfate decrease is driven by the decline of sulfur dioxide $\left(\mathrm{SO}_{2}\right)$ emissions from coal combustion (Hand et al., $2012 \mathrm{~b}$ ), though the mechanisms responsible for oxidation of $\mathrm{SO}_{2}$ to sulfate are not well quantified. Better understanding of the mechanisms is important because dry deposition competes with oxidation as a sink of $\mathrm{SO}_{2}$, so that faster oxidation produces more sulfate (Chin and Jacob, 1996). Standard model mechanisms assume that $\mathrm{SO}_{2}$ is oxidized to sulfate by the hydroxyl radical $(\mathrm{OH})$ in the gas phase and by hydrogen peroxide $\left(\mathrm{H}_{2} \mathrm{O}_{2}\right)$ and ozone in clouds (aqueous phase). A model intercomparison by McKeen et al. (2007) for the northeast US revealed a general failure of models to reproduce observed sulfate concentrations, sometimes by a factor of 2 or more. This could reflect errors in oxidation mechanisms, oxidant concentrations, or frequency of cloud processing. Laboratory data suggest that stabilized Criegee intermediates (SCIs) formed from alkene ozonolysis could be important $\mathrm{SO}_{2}$ oxidants (Mauldin III et al., 2012; Welz et al., 2012), though their ability to produce sulfate may be limited by competing reactions with water vapor (Chao et al., 2015; Millet et al., 2015).

The factors controlling OA are highly uncertain. OA originates from anthropogenic, biogenic, and open-fire sources (de Gouw and Jimenez, 2009). It is directly emitted as primary OA (POA) and also produced in the atmosphere as secondary OA (SOA) from oxidation of volatile organic compounds (VOCs). Current models cannot reproduce observed OA variability, implying fundamental deficiencies in the model mechanisms (Heald et al., 2011; Spracklen et al., 2011; Tsigaridis et al., 2014). A key uncertainty for air quality policy is the fraction of OA that can be controlled (Carlton et al., 2010), as most of the carbon in SOA is thought to be biogenic in origin. Gas/particle partitioning of organic material depends on the pre-existing aerosol concentration (Pankow, 1994; Donahue et al., 2006), so that "biogenic" SOA may be enhanced in the presence of anthropogenic POA and SOA (Weber et al., 2007). The SOA yield from VOC oxidation also depends on the concentration of nitrogen oxide radicals $\left(\mathrm{NO}_{x} \equiv \mathrm{NO}+\mathrm{NO}_{2}\right.$ ) (Kroll et al., 2005, 2006; Chan et al., 2010; Hoyle et al., 2011; Xu et al., 2014). $\mathrm{NO}_{x}$ in the southeast US is mostly from fossil fuel combustion and is in decline due to emission controls (Russell et al., 2012), adding 


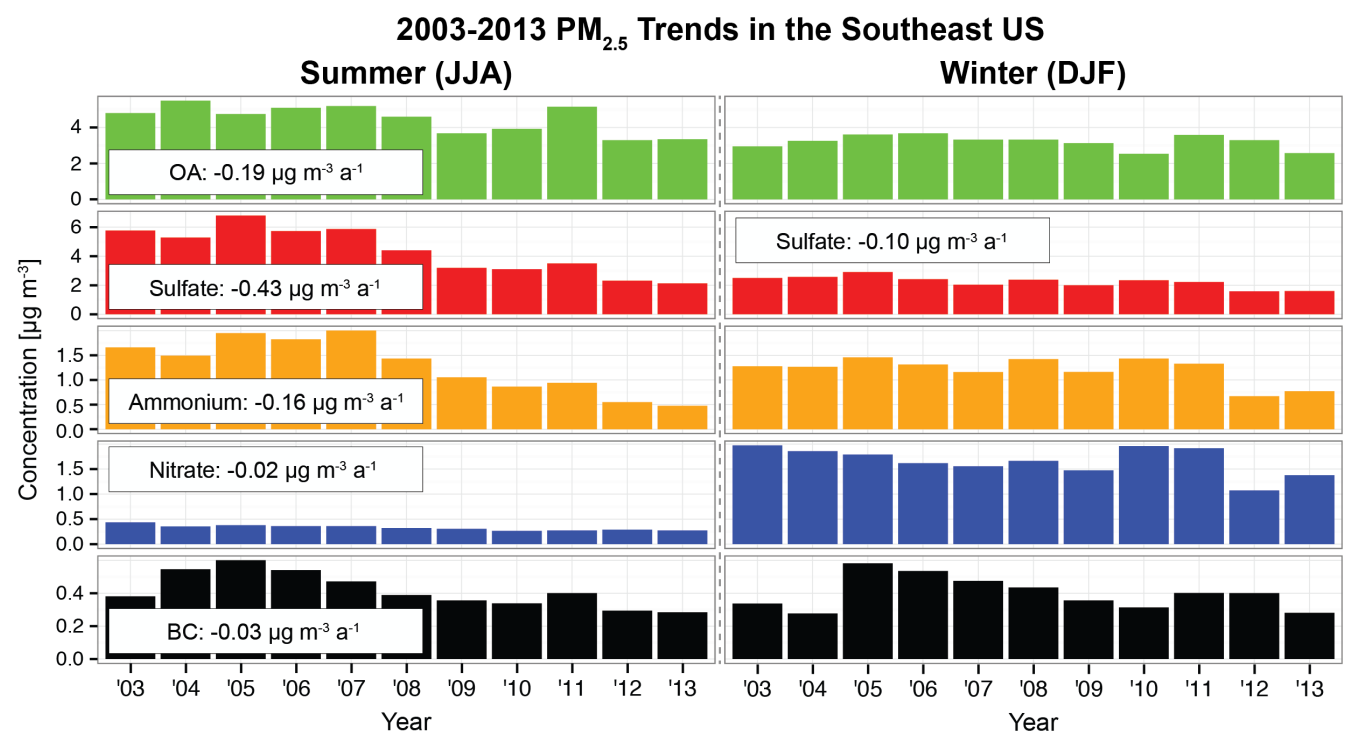

Figure 1. Summertime and wintertime trends in mean surface $\mathrm{PM}_{2.5}$ in the southeast US for 2003-2013. Seasonal averages for each component are calculated by combining data from the EPA CSN and IMPROVE networks over the southeast US domain defined in Fig. 2. Ammonium is only measured by CSN. Organic aerosol (OA) and black carbon (BC) are only from IMPROVE because of change in the CSN measurement protocol over the 2003-2013 period and differences in the OA measurements between the two networks (see text for details). $\mathrm{OA}$ is inferred here from measured organic carbon (OC) using an OA / OC mass ratio of 2.24 as measured by the Aerodyne Aerosol Mass Spectrometer (AMS) in the boundary layer over the southeast US. Note the different scales in different panels (sulfate and OA contribute most of $\mathrm{PM}_{2.5}$ ). Trends are calculated using the Theil-Sen estimator (Theil, 1950) and are shown only if significant at the $\alpha=0.05$ level. Only the sulfate trend is significant in winter.

another complication in the relationship between OA concentrations and anthropogenic sources. Oxidation of biogenic VOC by the $\mathrm{NO}_{3}$ radical formed from anthropogenic $\mathrm{NO}_{x}$ is also thought to be an important SOA source in the southeast US (Pye et al., 2010). Reactions of organic molecules with sulfate to form organosulfates may also play a small role (Surratt et al., 2007; Liao et al., 2015).

Long-term $\mathrm{PM}_{2.5}$ records for the southeast US are available from the EPA CSN, IMPROVE, and SEARCH networks of surface sites (Malm et al., 1994; Edgerton et al., 2005; Solomon et al., 2014). Satellite measurements of AOD from the MODIS and MISR instruments have been operating continuously since 2000 (Diner et al., 2005; Remer et al., 2005; Levy et al., 2013). Both surface and satellite observations show a strong aerosol seasonal cycle in the southeast US, with a maximum in summer and minimum in winter (A1ston et al., 2012; Hand et al., 2012a; Ford and Heald, 2013). Goldstein et al. (2009) observed that the amplitude of the seasonal cycle of $\mathrm{PM}_{2.5}$ measured at surface sites (maximum / minimum ratio of $\sim 1.5$; Hand et al., 2012a) is much smaller than the seasonal cycle of AOD measured from space (ratio of 3-4; Alston et al., 2012). They hypothesized that this could be due to a summertime source of biogenic SOA aloft. Subsequent work by Ford and Heald (2013) supported that hypothesis on the basis of spaceborne CALIOP lidar measurements of elevated light extinction above the planetary boundary layer (PBL).
The NASA SEAC ${ }^{4}$ RS aircraft campaign in AugustSeptember 2013 (Toon et al., 2015) offers a powerful resource for better understanding the factors controlling aerosol concentrations in the southeast US and the relationship between surface PM and AOD measured from space. The aircraft payload included measurements of aerosol composition, size distribution, and light extinction along with a comprehensive suite of aerosol precursors and related chemical tracers. Flights provided dense coverage of the southeast US (Fig. 2) including extensive PBL mapping and vertical profiling. AERONET sun photometers deployed across the region provided AOD measurements (Holben et al., 1998; http://aeronet.gsfc.nasa.gov/new_web/ dragon.html). Additional field campaigns focused on southeast US air quality during the summer of 2013 included SENEX (aircraft) and NOMADSS (aircraft) based in Tennessee (Warneke and the SENEX science team, 2015; http:// www.eol.ucar.edu/field_projects/nomadss), DISCOVER-AQ (aircraft) based in Houston (Crawford and Pickering, 2014), SOAS (surface) based in Alabama (http://soas2013.rutgers. edu), and SLAQRS (surface) based in Greater St. Louis (Baasandorj et al., 2015). We use the GEOS-Chem CTM with $0.25^{\circ} \times 0.3125^{\circ}$ horizontal resolution as a platform to exploit this ensemble of observational constraints by (1) determining the consistency between different measurements, (2) interpreting the measurements in terms of their implications for the sources of sulfate and OA in the southeast US, 


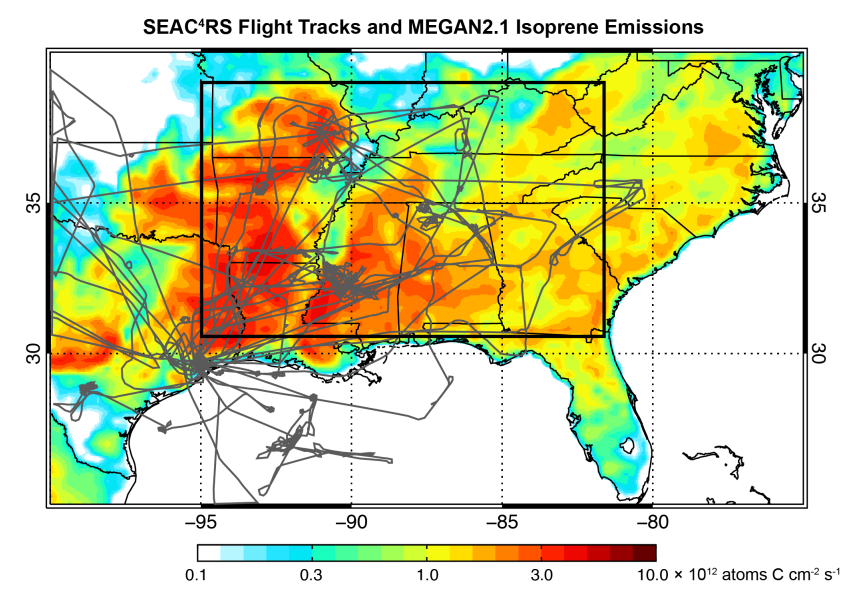

Figure 2. Flight tracks of the DC- 8 aircraft during SEAC ${ }^{4} \mathrm{RS}$, superimposed on mean MEGAN2.1 isoprene emissions for AugustSeptember 2013. The thick black line delineates the southeast US domain as defined in this paper $\left(95-81.5^{\circ} \mathrm{W}, 30.5-39^{\circ} \mathrm{N}\right)$.

(3) explaining the seasonal aerosol cycle in the satellite and surface data, and (4) assessing the ability of CTMs to relate satellite measurements of AOD to surface PM.

\section{The GEOS-Chem CTM}

GEOS-Chem has been used extensively to simulate aerosol concentrations over the US including comparisons to observations (Park et al., 2003, 2004, 2006; Drury et al., 2010; Heald et al., 2011, 2012; Leibensperger et al., 2012a; Walker et al., 2012; L. Zhang et al., 2012; Ford and Heald, 2013). Here we use GEOS-Chem version 9-02 (http://geos-chem. org) with detailed oxidant-aerosol chemistry and the updates described below. Our SEAC ${ }^{4} \mathrm{RS}$ simulation for AugustOctober 2013 is driven by Goddard Earth Observing System - Forward Processing (GEOS-FP) assimilated meteorological data from the NASA Global Modeling and Assimilation Office (GMAO). The GEOS-FP meteorological data have a native horizontal resolution of $0.25^{\circ} \times 0.3125^{\circ}$ $\left(\sim 25 \times 25 \mathrm{~km}^{2}\right)$ with 72 vertical pressure levels and $3 \mathrm{~h}$ temporal frequency ( $1 \mathrm{~h}$ for surface variables and mixed layer depths). The mixed layer (ML) is defined in GEOS-FP as the unstable surface-based column diagnosed from the potential temperature gradient, with a vertical resolution of $\sim 150 \mathrm{~m}$. It is used in GEOS-Chem for surface-driven vertical mixing following Lin and McElroy (2010). The representation of clouds and their properties, such as liquid water content, are taken from the GEOS-FP assimilated meteorological fields. We use the native resolution in GEOS-Chem over North America and adjacent oceans (130-60 W, 9.75$60^{\circ} \mathrm{N}$ ) to simulate the 1 August-31 October 2013 period with a 5-minute transport time step. This is nested within a global simulation at $4^{\circ} \times 5^{\circ}$ horizontal resolution to provide dynamic boundary conditions. The global simulation is ini- tialized on 1 June 2012 with climatological model fields and spun up for 14 months, effectively removing the sensitivity to initial conditions.

GEOS-Chem simulates the mass concentrations of all major aerosol components including sulfate, nitrate, and ammonium (SNA; Park et al., 2006; L. Zhang et al., 2012), organic carbon (OC; Heald et al., 2006, 2011; Fu et al., 2009), black carbon (BC; Wang et al., 2014), dust in four size bins (Fairlie et al., 2007), and sea salt in two size bins (Jaeglé et al., 2011). Aerosol chemistry is coupled to $\mathrm{HO}_{x}$ $\mathrm{NO}_{x}-\mathrm{VOC}-\mathrm{O}_{3}-\mathrm{BrO}_{x}$ tropospheric chemistry with recent updates to the isoprene oxidation mechanism as described by Mao et al. (2013). Gas/particle partitioning of SNA aerosol is computed with the ISORROPIA II thermodynamic module (Fontoukis and Nenes, 2007), as implemented in GEOSChem by Pye et al. (2009). Aerosol wet and dry deposition are described by Liu et al. (2001) and Zhang et al. (2001), respectively. $\mathrm{OC}$ is the carbon component of $\mathrm{OA}$, and we infer simulated OA from OC by assuming OA / OC mass ratios for different OC sources as given by Canagaratna et al. (2015). Model results are presented below either as OC or OA depending on the measurement to which they are compared. Measurements from surface networks are as OC while the aircraft measurements are as OA.

Table 1 lists GEOS-Chem emissions in the continental United States (CONUS) for 2013. Values for the southeast US in August-September are in parentheses. Emissions outside the CONUS are as in Kim et al. (2013) and are used in the global simulation to derive the boundary conditions for the nested grid. US anthropogenic emissions are from the EPA National Emissions Inventory for 2010 (NEI08v2). The NEI emissions are mapped over the $0.25^{\circ} \times 0.3125^{\circ}$ GEOS-Chem grid and scaled to the year 2013 by the ratio of national annual totals (http://www.epa.gov/ttnchie1/trends/). For $\mathrm{BC}$ and $\mathrm{SO}_{2}$ this implies 3 and $10 \%$ decreases from 2010 to 2013 , but we prescribe instead a $30 \%$ decrease for both to better match observed $\mathrm{BC}$ concentrations and trends in sulfate wet deposition. Our $\mathrm{SO}_{2}$ emission adjustment is more consistent with the latest version of the EPA inventory (NEI11v1), which indicates a $34 \%$ decline between 2010 and 2013, and with the observed trend in surface concentrations from the SEARCH network, which indicates a $~ 50 \%$ decline in the southeast US over the same years (Hidy et al., 2014). The NEI08 $\mathrm{NH}_{3}$ emissions are scaled to $2^{\circ} \times 2.5^{\circ}$ gridded monthly totals from the MASAGE inventory, which provides a good simulation of ammonium wet deposition in the US (Paulot et al., 2014).

Open fires have a pervasive influence on $\mathrm{OA}$ and $\mathrm{BC}$ over the US (Park et al., 2007). During SEAC ${ }^{4} \mathrm{RS}$, the southeast US was affected by both long-range transport of smoke from wildfires in the west (Peterson et al., 2015; Saide et al., 2015) and local agricultural fires. We use the Quick Fire Emissions Dataset (QFED2; Darmenov and da Silva, 2013), which provides daily open-fire emissions at $0.1^{\circ} \times 0.1^{\circ}$ resolution. Diurnal-scale factors, which vary by an order of mag- 
Table 1. Contiguous US (CONUS) emissions for $2013^{\mathrm{a}}$.

\begin{tabular}{|c|c|c|c|c|c|c|c|c|}
\hline Source & $\begin{array}{c}\mathrm{NO}_{x} \\
(\mathrm{Tg} \mathrm{N})\end{array}$ & $\begin{array}{l}\mathrm{CO} \\
(\mathrm{Tg})\end{array}$ & $\begin{array}{c}\mathrm{SO}_{2} \\
(\mathrm{Tg} \mathrm{S})\end{array}$ & $\begin{array}{l}\mathrm{NH}_{3} \\
(\mathrm{Tg})\end{array}$ & $\begin{array}{l}\mathrm{BC} \\
(\mathrm{Tg})\end{array}$ & $\begin{array}{l}\mathrm{OC} \\
(\mathrm{Tg})\end{array}$ & $\begin{array}{c}\text { Isoprene }^{b} \\
(\operatorname{Tg} \mathrm{C})\end{array}$ & $\begin{array}{c}\text { Monoterpenes } \mathrm{b} \\
(\operatorname{Tg} \mathrm{C})\end{array}$ \\
\hline Anthropogenic ${ }^{c}$ & $\begin{array}{c}2.7 \\
(0.07)\end{array}$ & $\begin{array}{c}29.8 \\
(0.65)\end{array}$ & $\begin{array}{c}2.8 \\
(0.14)\end{array}$ & $\begin{array}{c}3.5^{\mathrm{d}} \\
(0.11)\end{array}$ & $\begin{array}{c}0.26 \\
(0.008)\end{array}$ & $\begin{array}{c}0.58 \\
(0.01)\end{array}$ & - & - \\
\hline Open fires ${ }^{\mathrm{e}}$ & $\begin{array}{c}0.14 \\
(0.004)\end{array}$ & $\begin{array}{c}7.9 \\
(0.21)\end{array}$ & $\begin{array}{c}0.13 \\
(0.002)\end{array}$ & $\begin{array}{c}0.44 \\
(0.008)\end{array}$ & $\begin{array}{c}0.19 \\
(0.003)\end{array}$ & $\begin{array}{c}0.93 \\
(0.01)\end{array}$ & - & - \\
\hline Soil $^{\mathrm{f}}$ & $\begin{array}{c}0.69 \\
(0.03)\end{array}$ & - & - & - & - & - & - & - \\
\hline Vegetation & - & - & - & $\begin{array}{c}0.17 \\
(0.002)\end{array}$ & - & - & $\begin{array}{l}12.2 \\
(2.2)\end{array}$ & $\begin{array}{c}4.1 \\
(0.5)\end{array}$ \\
\hline Total & $\begin{array}{c}3.5 \\
(0.11)\end{array}$ & $\begin{array}{c}37.7 \\
(0.85)\end{array}$ & $\begin{array}{c}2.9 \\
(0.14)\end{array}$ & $\begin{array}{c}4.1 \\
(0.12)\end{array}$ & $\begin{array}{c}0.45 \\
(0.01)\end{array}$ & $\begin{array}{c}1.5 \\
(0.02)\end{array}$ & $\begin{array}{l}12.2 \\
(2.2)\end{array}$ & $\begin{array}{c}4.1 \\
(0.5)\end{array}$ \\
\hline
\end{tabular}

\footnotetext{
a Annual totals. Emissions in the southeast US for the 2-month SEAC ${ }^{4}$ RS period (August-September) are shown in parentheses. The southeast US domain is as defined in Fig. 2. ${ }^{\mathrm{b}}$ Biogenic VOC emissions are from the MEGAN2.1 inventory (Guenther et al., 2012) with isoprene emissions decreased by $15 \%$ (see text). ${ }^{\mathrm{c}}$ Anthropogenic emissions are from the EPA National Emissions Inventory (NEI08v2) scaled nationally to 2013 and with additional adjustments described in the text. ${ }^{\mathrm{d}}$ Agricultural ammonia emissions are from the MASAGE inventory on a $2^{\circ} \times 2.5^{\circ}$ grid (Paulot et al., 2014), and are distributed on the $0.25^{\circ} \times 0.3125^{\circ}$ grid following NEI08v2 as described in the text. ${ }^{\mathrm{e}}$ Open-fire emissions are from the Quick Fire Emissions Dataset (Darmenov and da Silva, 2013), with adjustments described in the text. ${ }^{\mathrm{f}}$ Soil and fertilizer $\mathrm{NO}_{x}$ emissions are from the BDSNP algorithm (Hudman et al., 2012). Fertilizer emissions are included in the anthropogenic total.
}

nitude between midday and evening and peak at 10:00-19:00 local time, are applied to the QFED2 daily emissions following recommendations from the Western Regional Air Partnership (WRAP, 2005) as in Saide et al. (2015). Following previous results from Turquety et al. (2007) and Fischer et al. (2014) for extratropical fires, we inject $35 \%$ of fire emissions above the boundary layer between 680 and $450 \mathrm{hPa}$ to account for plume buoyancy.

Biogenic VOC emissions are from the MEGAN2.1 inventory of Guenther et al. (2012) implemented in GEOS-Chem as described by L. Hu et al. (2015). Isoprene emissions are decreased by $15 \%$ to better match SEAC ${ }^{4} \mathrm{RS}$ observations of isoprene and formaldehyde concentrations and surface fluxes (Travis et al., 2015; Wolfe et al., 2015; Zhu et al., 2015). Figure 2 shows the SEAC ${ }^{4}$ RS DC- 8 flight tracks superimposed on the distribution of isoprene emissions. Total emissions over the southeast US (domain outlined in Fig. 2) during the 2-month $\mathrm{SEAC}^{4} \mathrm{RS}$ period were $2.2 \mathrm{Tg} \mathrm{C}$ for isoprene and $0.5 \mathrm{Tg} \mathrm{C}$ for monoterpenes. Monoterpene emissions did not exceed isoprene emission anywhere.

Sulfate was too low in our initial simulations of the SEAC ${ }^{4} \mathrm{RS}$ observations. We addressed this problem by including SCIs as additional $\mathrm{SO}_{2}$ oxidants in the model as previously implemented in GEOS-Chem by Pierce et al. (2013). Oxidation of isoprene and monoterpenes provides a large source of SCIs in the southeast US in summer. Sipilä et al. (2014) estimated SCI molar yields from ozonolysis of $0.58 \pm 0.26$ from isoprene, $0.15 \pm 0.07$ from $\alpha$-pinene, and $0.27 \pm 0.12$ from limonene. Sarwar et al. (2014) previously found that simulation of sulfate with the CMAQ CTM compared better with summertime surface observations in the southeast US when $\mathrm{SCI}+\mathrm{SO}_{2}$ reactions were included in the chemical mechanism. However, production of sulfate from
SCI chemistry may be severely limited by competition for SCIs between $\mathrm{SO}_{2}$ and water vapor, and depends on the respective reaction rate constants (Welz et al., 2012; Li et al., 2013; Newland et al., 2014; Sipilä et al., 2014; Stone et al., 2014). Here we use SCI chemistry from the Master Chemical Mechanism (MCMv3.2; Jenkin et al., 1997; Saunders et al., 2003) with the $\mathrm{SCI}+\mathrm{SO}_{2}$ and $\mathrm{SCI}+\mathrm{H}_{2} \mathrm{O}$ rate constants from Stone et al. (2014), using $\mathrm{CH}_{2} \mathrm{OO}$ as a proxy for all SCIs, such that the $\mathrm{SCI}+\mathrm{SO}_{2}$ pathway dominates. This would not be the case using the standard $\mathrm{SCI}+\mathrm{H}_{2} \mathrm{O}$ and significantly slower $(\sim 1000 \times) \mathrm{SCI}+\mathrm{SO}_{2}$ rate constants in MCM (Millet et al., 2015) or if reaction with the water vapor dimer is important (Chao et al., 2015). Given these crude approximations coupled with the uncertain SCI kinetics, the simulated SCI contribution to $\mathrm{SO}_{2}$ oxidation can be viewed as a proxy for missing oxidant or insufficient cloud processing in GEOS-Chem.

A number of mechanisms of varying complexity have been proposed to model OA chemistry (Donahue et al., 2006; Henze and Seinfeld, 2006; Ervens et al., 2011; Spracklen et al., 2011; Murphy et al., 2012; Barsanti et al., 2013; Hermansson et al., 2014). These mechanisms tend to be computationally expensive and have little success in reproducing the observed variability of OA concentrations (Tsigaridis et al., 2014). Here we use a simple linear approach to simulate five components of OA - anthropogenic POA and SOA, open-fire POA and SOA, and biogenic SOA. Anthropogenic and open-fire POA emissions are from the NEI08 and QFED2 inventories described above. For anthropogenic and open-fire SOA, we adopt the Hodzic and Jimenez (2011) empirical parameterization that assumes irreversible condensation of the oxidation products of $\mathrm{VOC}$ precursor gases (AVOC and BBVOC, respectively). AVOCs 
and BBVOCs are emitted in proportion to $\mathrm{CO}$, with an emission ratio of $0.069 \mathrm{~g} \mathrm{AVOC}(\mathrm{g} \mathrm{CO})^{-1}$ (Hayes et al., 2015) and $0.013 \mathrm{~g} \mathrm{BBVOC}(\mathrm{g} \mathrm{CO})^{-1}$ (Cubison et al., 2011). They are both oxidized by $\mathrm{OH}$ in the model with a rate constant of $1.25 \times 10^{-11} \mathrm{~cm}^{3}$ molecule ${ }^{-1} \mathrm{~s}^{-1}$ to generate SOA. This approach produces amounts of SOA and timescales of formation consistent with field measurements at many locations (de Gouw and Jimenez, 2009; Hodzic and Jimenez, 2010; Cubison et al., 2011; Jolleys et al., 2012; Hayes et al., 2015).

We assume biogenic SOA to be produced with a yield of $3 \%$ from isoprene and $5 \%$ from monoterpenes, formed at the point of emission. Laboratory studies have shown that different biogenic SOA formation mechanisms operate depending on the $\mathrm{NO}$ concentration, which determines the fate of the organic peroxy radicals $\left(\mathrm{RO}_{2}\right)$ produced from VOC oxidation (Kroll et al., 2005, 2006; Chan et al., 2010; Xu et al., 2014). In the high-NO pathway, the $\mathrm{RO}_{2}$ radicals react with $\mathrm{NO}$, while in the low-NO pathway, they react with $\mathrm{HO}_{2}$, other $\mathrm{RO}_{2}$ radicals, or isomerize. During SEAC ${ }^{4} \mathrm{RS}$ the two pathways were of comparable importance (Travis et al., 2015). We use four separate tracers in the model to track SOA formed from isoprene and monoterpenes via the high- and low-NO pathways. This tracer separation is purely diagnostic as the SOA yields are assumed here to be the same in both pathways. The SOA is apportioned to the high- or low-NO tracer by the fraction of $\mathrm{RO}_{2}$ reacting with $\mathrm{NO}$ at the point and time of emission. A more mechanistic GEOS-Chem simulation of isoprene SOA in SEAC ${ }^{4} \mathrm{RS}$ including irreversible aqueous-phase formation coupled to gas-phase chemistry is presented by Marais et al. (2015). It finds in particular that the mean isoprene SOA yield in the low-NO pathway is twice that in the high-NO pathway.

GEOS-Chem computes the AOD for each aerosol component $i$ by summing the optical depths over all vertical model layers $L=[1, \ldots, n]$ :

$\mathrm{AOD}=\sum_{i} \sum_{L=1}^{n} \alpha_{i}(L) M_{i}(L)$,

where $\alpha_{i}(L)$ and $M_{i}(L)$, respectively, are the component mass extinction efficiency $\left(\mathrm{m}^{2} \mathrm{~g}^{-1}\right)$ and partial column mass $\left(\mathrm{g} \mathrm{m}^{-2}\right.$ ) for level $L$. The $\alpha_{i}$ values are pre-calculated for selected wavelengths using a standard Mie scattering algorithm. The algorithm assumes specified aerosol dry size distributions and optical properties from the Global Aerosol Data Set (GADS; Koepke et al., 1997), with updates by Drury et al. (2010) on the basis of summer observations from the ICARTT aircraft campaign over the eastern US. The mass extinction efficiencies are then adjusted for hygroscopic growth as a function of the local relative humidity ( $\mathrm{RH})$, following Martin et al. (2003). The total AOD is reported here at $550 \mathrm{~nm}$ and is the sum of the contributions from all aerosol components. Comparison of dry aerosol size distribution and hygroscopic growth show good general agreement with observations similar to Drury et al. (2010) (Supplement).
Comparison of GEOS-FP ML heights with lidar and ceilometer data from SEAC ${ }^{4} \mathrm{RS}$, SOAS, and DISCOVERAQ indicates a $30-50 \%$ positive bias across the southeast US in daytime (Scarino et al., 2014b; Millet et al., 2015). We decrease the daytime GEOS-FP ML heights by $40 \%$ in our simulation to correct for this bias. During SEAC ${ }^{4} \mathrm{RS}$, ML heights were measured by the NASA-Langley High Spectral Resolution Lidar (HSRL; Hair et al., 2008; Scarino et al., 2014a) on the basis of aerosol gradients under clear-sky conditions. After correction, the modeled ML height is typically within $10 \%$ of the HSRL data along the SEAC ${ }^{4}$ RS flight tracks, with a mean daytime value ( \pm 1 standard deviation) of $1690 \pm 440 \mathrm{~m}$ in the HSRL data and $1530 \pm 330 \mathrm{~m}$ in the model (Zhu et al., 2015). The daytime ML was typically capped by a shallow cloud convective layer (CCL) extending up to about $3 \mathrm{~km}$, capped in turn by a subsidence inversion and the free troposphere above. When giving column statistics we will refer to the ML as below $1.5 \mathrm{~km}$ and the CCL as between 1.5 and $3 \mathrm{~km}$.

Our simulation of sulfate and OA differs in a number of ways from previous GEOS-Chem simulations using earlier versions of the model (Park et al., 2004, 2006; Heald et al., 2006; Leibensperger et al., 2012a; Zhang et al., 2012; Ford and Heald, 2013). Benchmark simulations of ${ }^{210} \mathrm{~Pb}$ aerosol (Liu et al., 2001; http://acmg.seas.harvard.edu/geos/ geos_benchmark.html) show that the global mean aerosol lifetime against deposition is $15 \%$ shorter with the GEOS-FP meteorological data used here than with the previously used GEOS-5 data. Correcting the ML height bias over the southeast US in the GEOS-FP data increases our simulated $\mathrm{PM}_{2.5}$ concentrations by $15-25 \%$. Previous GEOS-Chem studies did not include the Criegee biradical mechanism for $\mathrm{SO}_{2}$ oxidation, which in our simulation increases the mean sulfate concentrations over the southeast US by $50 \%$ and increases the $\mathrm{SO}_{2}$ / sulfate ratio to better agree with observations (Sect. 4). The default SOA mechanism in GEOS-Chem, based on reversible partitioning of semivolatile products of VOC oxidation (Pye et al., 2010), underestimates OA levels during SEAC ${ }^{4} \mathrm{RS}$ by a factor of 3 (Marais et al., 2015). The simple SOA parameterization used here effectively assumes irreversible uptake as a mechanism for SOA formation and provides a much improved simulation of OA over the southeast US, as shown below. Marais et al. (2015) present a more mechanistic treatment of isoprene SOA formation in GEOSChem, based on irreversible uptake in aqueous aerosols, in their simulation of SEAC ${ }^{4} \mathrm{RS}$ observations. Their mean SOA yield from isoprene $(3.3 \%)$ is comparable to our imposed value of $3 \%$ but accounts for $\mathrm{NO}_{x}$ dependence.

Several companion papers apply the same GEOS-Chem model configuration as described here to other analyses of the SEAC ${ }^{4} \mathrm{RS}$ data focused on gas-phase chemistry. These include investigation of the factors controlling ozone in the southeast US (Travis et al., 2015), isoprene chemistry and the formation of organic nitrates (Fisher et al., 2015), validation of satellite $\mathrm{HCHO}$ data as constraints on isoprene emissions 
(Zhu et al., 2015), and the sensitivity of model concentrations and processes to grid resolution (Yu et al., 2015). These studies include extensive comparisons to the gas-phase observations in $\mathrm{SEAC}^{4} \mathrm{RS}$. Our focus here will be on the aerosol observations.

\section{Surface aerosol concentrations}

We begin by evaluating the simulation of $\mathrm{PM}_{2.5}$ and its components against ground observations. Total $\mathrm{PM}_{2.5}$ is measured gravimetrically at $35 \% \mathrm{RH}$ at a large number of EPA monitoring sites (Fig. 3). Filter-based measurements of $\mathrm{PM}_{2.5}$ composition are taken every 3 days at surface networks including the EPA CSN (25 sites in the study domain marked in Fig. 2, mostly in urban areas), IMPROVE (15 sites, mostly in rural areas), and SEARCH (5 sites, urban and suburban/rural). These three networks all provide 24-hour average concentrations of the major ions (SNA), carbon species (BC and OC), and dust, though there are differences in protocols (Edgerton et al., 2005; Hidy et al., 2014; Solomon et al., 2014), in particular with respect to OC artifact correction. The IMPROVE and SEARCH OC are both blank-corrected but in different ways (Dillner et al., 2009; Chow et al., 2010), while CSN OC is uncorrected. We apply a constant $0.3 \mu \mathrm{g} \mathrm{m}^{-3}$ background correction to the CSN OC data as in Hand et al. (2012a). The resulting CSN OC measurements are within $1 \%$ of SEARCH and $44 \%$ higher than IMPROVE when averaged across the southeast US. When necessary, OA is inferred from the OC filter samples using an OA / OC mass ratio of 2.24 as measured in the boundary layer during $\mathrm{SEAC}^{4} \mathrm{RS}$ by an aerosol mass spectrometer (AMS) onboard the DC-8 aircraft (Sect. 4). We do not discuss sea-salt concentrations as they make a negligible contribution to $\mathrm{PM}_{2.5}$ inland $\left(<0.1 \mu \mathrm{g} \mathrm{m}^{-3}\right.$ averaged across the EPA networks).

Figure 3 shows mean August-September $2013 \mathrm{PM}_{2.5}$ at the EPA sites and compares it to GEOS-Chem values. Concentrations peak over Arkansas, Louisiana, and Mississippi, corresponding to the region of maximum isoprene emission in Fig. 2. The spatial distribution and composition of $\mathrm{PM}_{2.5}$ is otherwise fairly homogeneous across the southeast US, reflecting coherent stagnation, mixing, and ventilation of the region (X. Zhang et al., 2012; Pfister et al., 2015). Sulfate accounts on average for $25 \%$ of $\mathrm{PM}_{2.5}$, while OA accounts for $55 \%$. GEOS-Chem captures the broad features shown in the surface station $\mathrm{PM}_{2.5}$ data with little bias $(R=0.65$, normalized mean bias or NMB $=-1.4 \%$ ). The model hotspot in southern Arkansas is due to OA from a combination of biogenic emissions and agricultural fires. As discussed below, agricultural fires make only a small contribution on a regional scale.

The spatial distributions of sulfate and OC concentrations are shown in Fig. 4. The observed and simulated sulfate maxima are shifted to the northeast relative to total $\mathrm{PM}_{2.5}$, shown

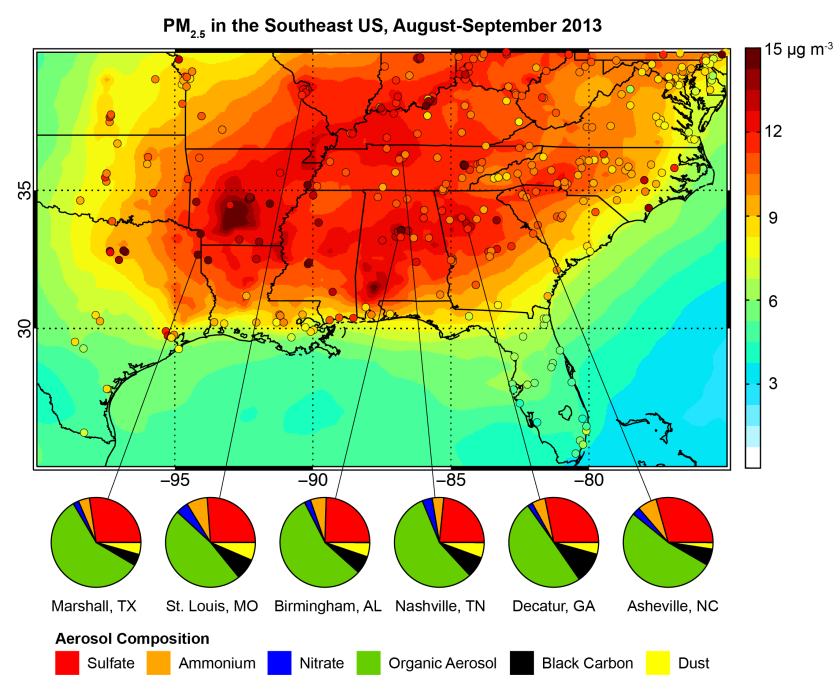

Figure 3. Mean $\mathrm{PM}_{2.5}$ in the southeast US in AugustSeptember 2013. EPA observations (circles) are compared to GEOS-Chem model values (background). Model values are calculated at $35 \%$ relative humidity as per the Federal Reference Method protocol. Observed mean $\mathrm{PM}_{2.5}$ speciation by mass is shown in the pie charts for representative CSN sites. Organic aerosol (OA) mass concentrations are derived from measurements of organic carbon (OC) by assuming an OA / OC mass ratio of 2.24.

in Fig. 3. GEOS-Chem captures a larger fraction of the observed variability at rural sites $(R=0.78$ for IMPROVE) than at urban/suburban sites $(R=0.71$ for SEARCH, 0.62 for CSN) as would be expected from the sub-grid scale of urban pollution. A scatter plot of the simulated daily mean surface sulfate concentrations compared to the filter observations from all three networks in August-September 2013 is shown in the Supplement. The model bias (NMB) is $+5 \%$ relative to IMPROVE, $+10 \%$ relative to $\mathrm{SEARCH}$, and $+9 \%$ relative to CSN. Over the southeast US domain defined in Fig. 2, $42 \%$ of sulfate production is from in-cloud production by $\mathrm{H}_{2} \mathrm{O}_{2}, 22 \%$ is from gas-phase oxidation by $\mathrm{OH}$, and $36 \%$ is from gas-phase oxidation by SCIs. Previous studies by Pierce et al. (2013) and Boy et al. (2013) found similarly large contributions of SCIs to sulfate production over forested regions in summer. However, there is substantial uncertainty in the SCI kinetics, as discussed above, and it is possible that other oxidants are responsible for the missing sulfate (hence the "Other" label in Fig. 4).

The observed OC distribution shows a decreasing gradient from southwest to northeast that maps onto the distribution of isoprene emissions shown in Fig. 2. The IMPROVE OC is generally low compared to CSN and SEARCH, as has been noted previously (Ford and Heald, 2013; Attwood et al., 2014). GEOS-Chem reproduces the broad features of the observed OC distribution with moderate skill in capturing the variability ( $R=0.64$ for IMPROVE, 0.62 for SEARCH, 0.61 for CSN). Model OC is biased high with a NMB of $+66 \%$ 

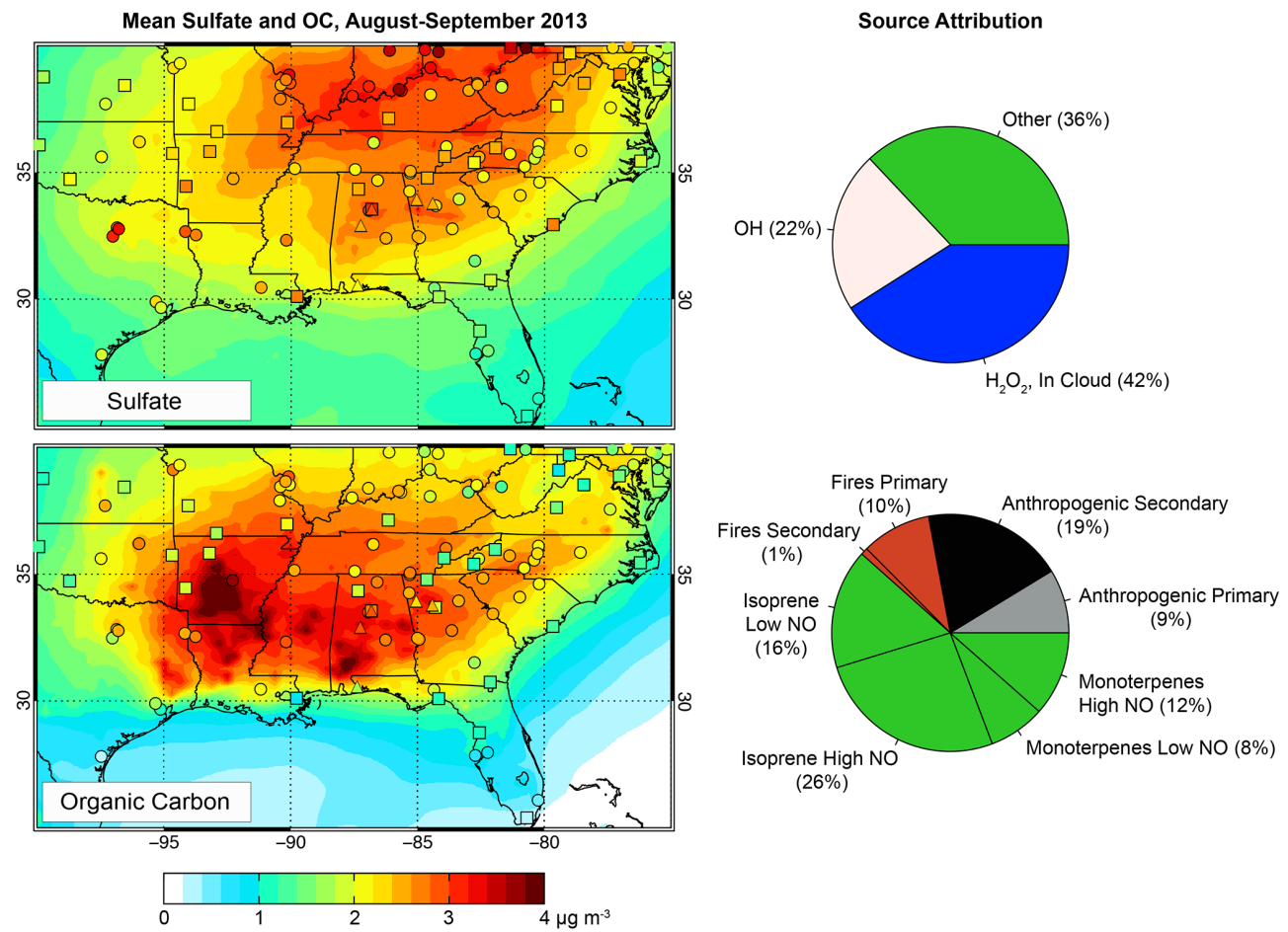

$(26 \%)$

Figure 4. Mean sulfate (top) and OC (bottom) surface air concentrations in the southeast US in August-September 2013. Network observations from CSN (circles), IMPROVE (squares), and SEARCH (triangles) are compared to GEOS-Chem model values (background). OC measurements are artifact-corrected as described in the text. Source attribution for sulfate and OC is shown on the right as averages for the southeast US domain defined in Fig. 2. For sulfate, source attribution is by $\mathrm{SO}_{2}$ oxidant. For OC, source attribution is primary or secondary, by source type, and by NO regime.

for IMPROVE, $+29 \%$ for SEARCH, and $+14 \%$ for CSN. The range of NMBs for the different networks could reflect differences in measurement protocols described above - IMPROVE OC is lower than SEARCH by $27 \%$ for collocated measurements made at Birmingham, Alabama (Supplement). We discuss this further in the next section in the context of the aircraft data.

Source attribution of OC in the model (Fig. 4) suggests a dominance of biogenic sources. Isoprene alone contributes $42 \%$ of the regional OC burden. This is in contrast with previous work by Barsanti et al. (2013), who fitted chamber observations to a model mechanism and found monoterpenes to be as or more important than isoprene as a source of OC in the southeast US (particularly under low-NO conditions). SEAC ${ }^{4} \mathrm{RS}$ observations support a significant role of isoprene as a source of OA (W. W. Hu et al., 2015; Campuzano-Jost et al., 2014; Liao et al., 2015).

Anthropogenic sources in the model contribute $28 \%$ to regional OC, roughly evenly distributed across the region. Open fires contribute $11 \%$, mainly from agricultural fires in Arkansas and Missouri. Influence from western US fires is significant in the free troposphere (see Sect. 4) but not at the surface.

When all of the components are taken together, we find that $81 \%$ of the surface OC in the southeast US is sec- ondary in origin. This is well above the 30-69\% range of previous literature estimates for the region (Lim and Turpin, 2002; Yu et al., 2004; Kleindienst et al., 2007; Blanchard et al., 2008) and likely reflects the decreasing trend in anthropogenic emissions (Fig. 1) and possibly a low bias in some estimation methods (Docherty et al., 2008). Assuming fossil fractions of 50 and $70 \%$ for anthropogenic primary and secondary OC, respectively (Zotter et al., 2014; Hayes et al., 2015 ), we estimate that $18 \%$ of the total OC burden is derived from fossil fuel use. This is consistent with an $18 \%$ fossil fraction from radiocarbon measurements made on filter samples collected in Alabama during SOAS (Edgerton and the SOAS science team, 2014).

\section{Aerosol vertical profile}

We now examine the aerosol vertical distribution measured by the NASA DC- 8 aircraft and simulated by GEOS-Chem along the flight tracks on 18 flights over the southeast US (Fig. 2). Aerosol mass composition was measured by the High-Resolution Aerodyne AMS for SNA and OA (Canagaratna et al., 2007) and by the NOAA humidified dual single-particle soot photometer for BC (HD-SP2; Schwarz et al., 2015). Dust concentrations were measured from filter 


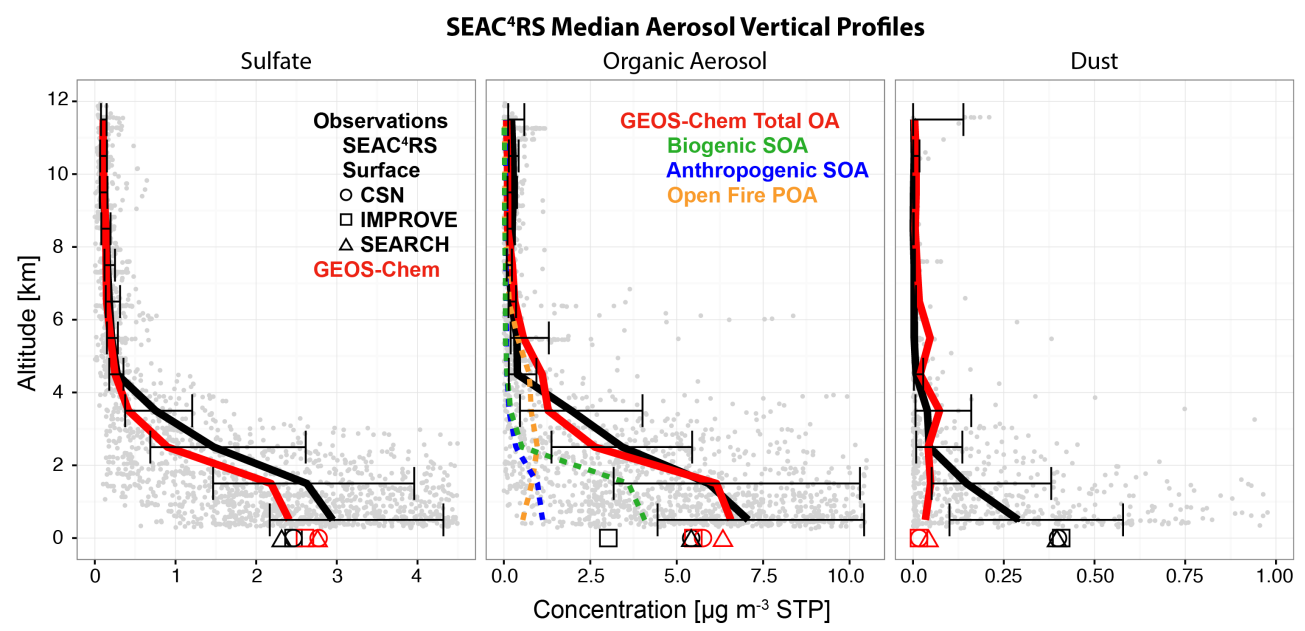

Figure 5. Median vertical profiles of aerosol concentrations over the southeast US (Fig. 2) during the SEAC ${ }^{4}$ RS aircraft campaign (AugustSeptember 2013). Observed and simulated profiles of sulfate (left), OA (center), and dust (right) in $1 \mathrm{~km}$ bins are shown with the corresponding median surface network observations. OC from the surface networks is converted to OA using an OA / OC ratio of 2.24. The contributions of anthropogenic SOA, biogenic SOA, and open-fire POA to total simulated OA are also shown. The individual observations are shown in gray and the horizontal bars denote the 25 th and 75 th percentiles of the observations. Concentrations are in $\mu \mathrm{g} \mathrm{m}{ }^{-3}, \mathrm{converted}$ to STP conditions for the aircraft data and under local conditions for the surface data. The choice of scale truncates some very large individual observations.

samples (Dibb et al., 2003), but the ML values are $\sim 10 \times$ higher than measured by surface networks or simulated in GEOS-Chem, as previously found by Drury et al. (2010) during ICARTT. Instead we estimate dust concentrations from Particle Analysis by Laser Mass Spectrometer (PALMS) measurements (Thomson et al., 2000; Murphy et al., 2006). The PALMS data provide the size-resolved number fraction of dust-containing particles, which is multiplied by the measured aerosol volume size distribution from the LAS instrument (Thornhill et al., 2008; Chen et al., 2011) and an assumed density of $2.5 \mathrm{~g} \mathrm{~cm}^{-3}$. The size distribution is truncated to $\mathrm{PM}_{2.5}$ by applying the transmission curve for the $2.5 \mu \mathrm{m}$ aerosol impactor used by the ground networks.

Figure 5 shows the median sulfate, OA, and dust vertical profiles over the southeast US. Also shown are the median concentrations from the surface networks over the study domain shown in Fig. 2. The difference between the surface and aircraft data that can be attributed to differences in sampling (time and duration) is quantified by the difference in GEOSChem output when the model is sampled with the surface data vs. when the model is sampled with the aircraft data. For sulfate, the model underestimates the aircraft observations by $20 \%$ below $5 \mathrm{~km}$ but overestimates the surface observations by $5-10 \%$ as discussed in Sect. 3. The general shape of the vertical profile is well simulated (with a low bias from 3 to $4 \mathrm{~km}$ ) and this applies also to $\mathrm{SO}_{2}$ and to the $\mathrm{SO}_{2} /$ sulfate ratio (Supplement). The sulfate concentrations are highest near the surface and drop rapidly with altitude, but there is significant mass loading in the lower free troposphere. $23 \%$ of the observed sulfate column mass lies in the free troposphere above $3 \mathrm{~km}$ and this is well simulated by the model
( $23 \%)$. Analysis of SENEX and SEAC ${ }^{4}$ RS vertical profiles by Wagner et al. (2015) suggests that most of this free tropospheric sulfate is ventilated from the PBL rather than being produced within the free troposphere from ventilated $\mathrm{SO}_{2}$. GEOS-Chem shows moderate skill in explaining the variability in the aircraft sulfate data $(R=0.81$ for all observations in the southeast US, $R=0.68$ below $3 \mathrm{~km}, R=0.49$ above $3 \mathrm{~km}$ ).

Similarly to sulfate, OA measured from aircraft peaks at the surface and decreases rapidly with height (Fig. 5). The aircraft OA mass concentration below $1 \mathrm{~km}$ is $25-50 \%$ higher than measured at the surface networks. IMPROVE is substantially lower than the other networks, as has been noted above and in previous studies (Ford and Heald, 2013; Attwood et al., 2014), and may be due to instrumental issues particular to that network. The discrepancy between the AMS observations and CSN/SEARCH can largely be explained by differences in sampling, as shown by the model. The GEOSChem simulation matches closely the aircraft observations. The vertical distribution of OA is similar to that of sulfate, with $20 \%$ of the total column being above $3 \mathrm{~km}$ both in the model and in the observations. The GEOS-Chem source attribution, also shown in Fig. 5, indicates that open fires contribute $\sim 50 \%$ of OA in the free troposphere. This fire influence is seen in the observations as occasional plumes of OA up to $6-7 \mathrm{~km}$ altitude (individual gray dots in Fig. 5). Fire plumes can be problematic for interpreting the AOD / PM relationship for individual scenes but much less so in a temporal average as the mean influence on the column is small. Simulating fire influence successfully in the model does require buoyant injection of western US wildfire emissions in 


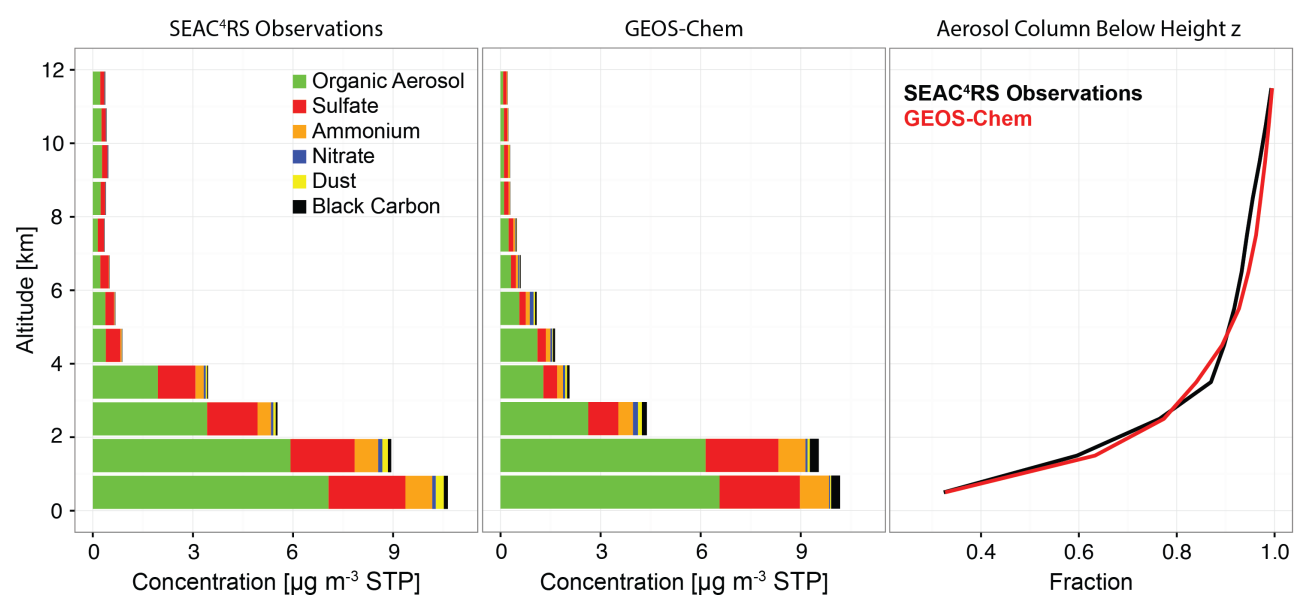

Figure 6. Median vertical profiles of aerosol composition over the southeast US during SEAC ${ }^{4}$ RS (August-September 2013). Observations from the DC-8 aircraft (left) are compared to GEOS-Chem values sampled at the aircraft times and locations (center). Also shown is the observed and simulated fraction of the total aerosol mass column below a given height (right). The southeast US domain is as defined in Fig. 2.

the free troposphere, as noted in previous studies (Turquety et al., 2007; Fischer et al., 2014).

Comparison of GEOS-Chem to the individual OA observations along the aircraft flight tracks shows good simulation of the variability ( $R=0.82$ for all observations, $R=0.74$ below $3 \mathrm{~km}, R=0.42$ above $3 \mathrm{~km}$ ). This is despite (or maybe because of) our use of a very simple parameterization for the OA source. Further GEOS-Chem comparison to SEAC ${ }^{4} \mathrm{RS}$ and SOAS observations is presented by Marais et al. (2015) using a more mechanistic analysis of SOA. The successful GEOS-Chem simulation of the OA vertical profile argues against a large CCL source from aqueous-phase cloud processing. This is supported by the work of Wagner et al. (2015), who found little OA enhancement in air masses processed by cumulus wet convection.

Dust made only a minor contribution to total aerosol mass in the southeast US during SEAC ${ }^{4} \mathrm{RS}$, accounting for less than $10 \%$ of observed surface $\mathrm{PM}_{2.5}$ (Fig. 3). The PBL dust concentrations measured by PALMS are roughly consistent with the surface data but the model is much lower (Fig. 5). This reflects a southward bias in the model transport of Saharan dust (Fairlie et al., 2007), but is of little consequence for the simulation of $\mathrm{PM}_{2.5}$ or the AOD / PM relationship over the southeast US. Figure 5 shows few free tropospheric plumes in the SEAC ${ }^{4} \mathrm{RS}$ observations, consistent with the dust climatology compiled from CALIOP data by Liu et al. (2008).

Figure 6 compiles the median observed and simulated vertical profiles of aerosol concentrations and composition during SEAC ${ }^{4}$ RS. OA and sulfate dominate at all altitudes. Ammonium is associated with sulfate as discussed in the next Section. OA accounts for most of $\mathrm{PM}_{2.5}$ below $1 \mathrm{~km}$, with a mass fraction $F_{\mathrm{OA}}=[\mathrm{OA}] /\left[\mathrm{PM}_{2.5}\right]$ of $0.62 \mathrm{~g} \mathrm{~g}^{-1}(0.65$ in GEOS-Chem). This is consistent with the surface SEARCH data $\left(F_{\mathrm{OA}}=0.56 \mathrm{gg}^{-1}\right)$. Figure 1 shows a lower $F_{\mathrm{OA}}$ in the IMPROVE surface observations, increasing from $0.34 \mathrm{~g} \mathrm{~g}^{-1}$ in 2003 to $0.44 \mathrm{~g} \mathrm{~g}^{-1}$ in 2013 , reflecting instrumentation bias as discussed above. The aircraft data show that most of the aerosol mass is OA at all altitudes. The aerosol column is mostly in the PBL $(60 \%$ in the ML, $25 \%$ in the CCL), but $\sim 15 \%$ is in the free troposphere with $10 \%$ above $5 \mathrm{~km}$ (Fig. 6, right panel). GEOS-Chem reproduces the observed shape of the vertical distribution of total aerosol mass, and this is an important result for application of the model to derive the AOD-PM relationship.

\section{Extent of neutralization of sulfate aerosol}

The extent of neutralization of sulfate aerosol by ammonia, computed from the fraction $f=\left[\mathrm{NH}_{4}^{+}\right] /\left(2\left[\mathrm{SO}_{4}^{2-}\right]+\left[\mathrm{NO}_{3}^{-}\right]\right)$, where concentrations are molar, has important implications for the aerosol phase and hygroscopicity, for the formation of aerosol nitrate (Martin et al., 2004; Wang et al., 2008), and for the formation of SOA (Froyd et al., 2010; Eddingsaas et al., 2010; McNeill et al., 2012; Budisulistiorini et al., 2013; Liao et al., 2015). Figure 6 shows ammonium to be the third most important aerosol component by mass in the southeast US in summer after OA and sulfate. Summertime particle-phase ammonium concentrations have declined at approximately the same rate as sulfate from 2003 to 2013 (Fig. 1 and Blanchard et al., 2013). However, we find no significant trend over that time in ammonium wet deposition fluxes over the southeast US (NADP, 2015), in contrast to a $\sim 50 \%$ decline in sulfate wet deposition. This implies that ammonia emissions have not decreased but the partitioning into the aerosol has. 

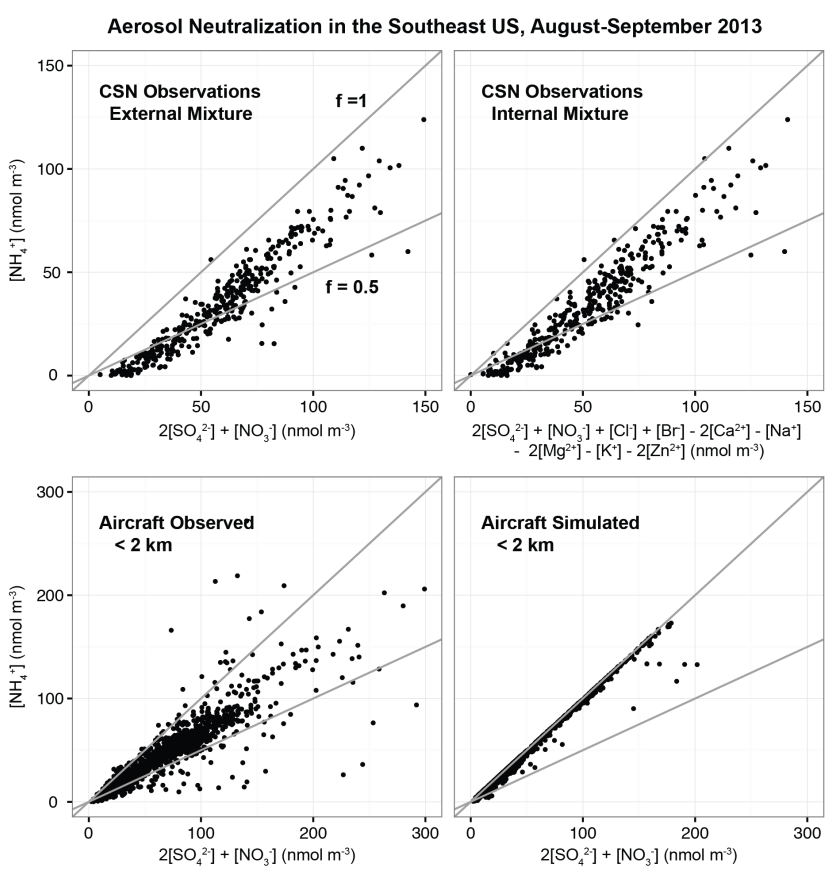

Figure 7. Extent of neutralization of sulfate aerosol in the southeast US (August-September 2013). The extent of neutralization for an external sulfate-nitrate-ammonium (SNA) mixture is given by the $f=\left[\mathrm{NH}_{4}^{+}\right] /\left(2\left[\mathrm{SO}_{4}^{2-}\right]+\left[\mathrm{NO}_{3}^{-}\right]\right)$molar ratio, and this can be adjusted for an internal mixture by considering additional ions. The top panels show observations from the CSN network, assuming an external (left) or internal (right) mixture; there is little difference between the two because the concentrations of additional ions are usually small. The bottom panels show the SEAC ${ }^{4} \mathrm{RS}$ aircraft observations below $2 \mathrm{~km}$ and the corresponding GEOS-Chem values. Also shown are the lines corresponding to different extents of neutralization ( $f=0.5$ for ammonium bisulfate and $f=1$ for ammonium sulfate).

One would expect ammonium aerosol trends to follow those of sulfate if the aerosol is fully neutralized $(f=1)$, so that partitioning of ammonia into the aerosol phase is limited by the supply of sulfate. However, this is not the case in the observations. Figure 7 shows the extent of neutralization in the observations and the model, assuming that the SNA aerosol is externally mixed from other ionic aerosol components such as dust. The model aerosol is fully neutralized $(f=1)$ but the observed aerosol is not, with a median extent of neutralization of $0.55 \mathrm{~mol} \mathrm{~mol}^{-1}$ in the CSN data and $0.68 \mathrm{~mol} \mathrm{~mol}^{-1}$ in the AMS data below $2 \mathrm{~km}$. This is comparable to $f=0.49 \mathrm{~mol} \mathrm{~mol}^{-1}$ observed at the SOAS Centreville site earlier in the summer. The CSN data include full ionic analysis and we examined whether internal mixing of SNA aerosol with other ions could affect the extent of neutralization. The top right panel of Fig. 7 shows that it does not, reflecting the low concentrations of these other ions. The AMS reports total sulfate. While organosulfates have a low $\mathrm{pKa}$ and would interact with ammonium as a single charged

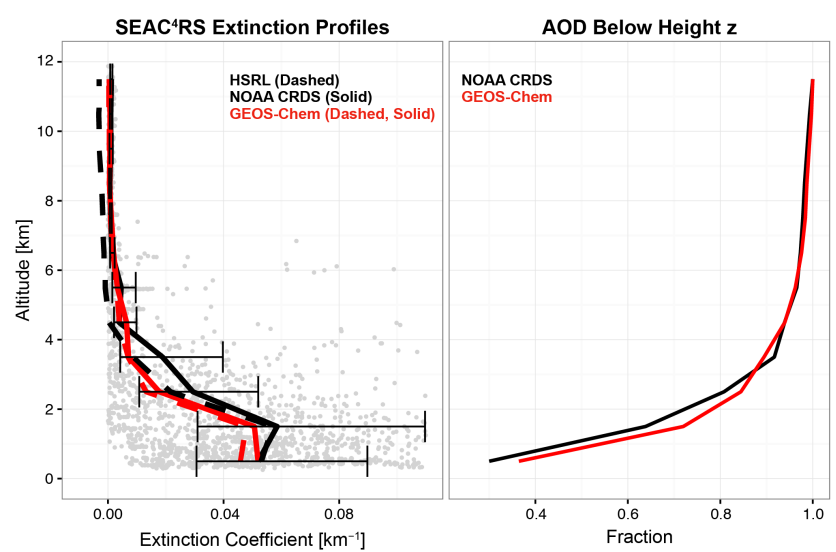

Figure 8. Median vertical profiles of aerosol extinction coefficients $(532 \mathrm{~nm})$ over the southeast US during SEAC ${ }^{4} \mathrm{RS}$. The left panel shows independent observations from the NASA HSRL and NOAA CRDS instruments, with GEOS-Chem sampled at the times and locations of the available instrument data. The individual CRDS observations are shown in gray and the horizontal bars denote the 25th and 75th percentiles of the CRDS observations for each $1 \mathrm{~km}$ bin. The choice of scale truncates some very large individual observations. The right panel shows the observed (CRDS) and simulated fraction of the total AOD below a given height. The southeast US domain is as defined in Fig. 2.

ion, they were typically a small fraction of total sulfate (Liao et al., 2015).

A possible explanation is that ammonia uptake by aerosol with $f<1$ may be inhibited by organic particle material. This has been demonstrated in a laboratory study by Liggio et al. (2011), who show that the time constant for ammonia to be taken up by sulfate aerosol with incomplete extent of neutralization increases with the ratio of condensing organic gases to sulfate and may be hours to days.

The complete extent of neutralization of sulfate aerosol in the model, in contrast to the observations, leads to bias in the simulated aerosol phase and hygroscopicity for relating AOD to PM. Calculations by Wang et al. (2008) for ammoniumsulfate particles of different compositions show a 10-20\% sensitivity of the mass extinction efficiency to the extent of neutralization, with the effect changing sign depending on composition and RH. An additional effect of $f=1$ in the model would be to allow formation of ammonium nitrate aerosol, but nitrate aerosol is negligibly small in the model as it is in the observations (Fig. 6). At the high temperatures over the southeast US in the summer, we find in the model that the product of $\mathrm{HNO}_{3}$ and $\mathrm{NH}_{3}$ partial pressures is generally below the equilibrium constant for formation of nitrate aerosol. By contrast, surface network observations in winter show nitrate to be a large component of surface $\mathrm{PM}_{2.5}$ (Fig. 1; Hand et al., 2012b; Ford and Heald, 2013), reflecting both lower temperatures and the lower levels of sulfate. 


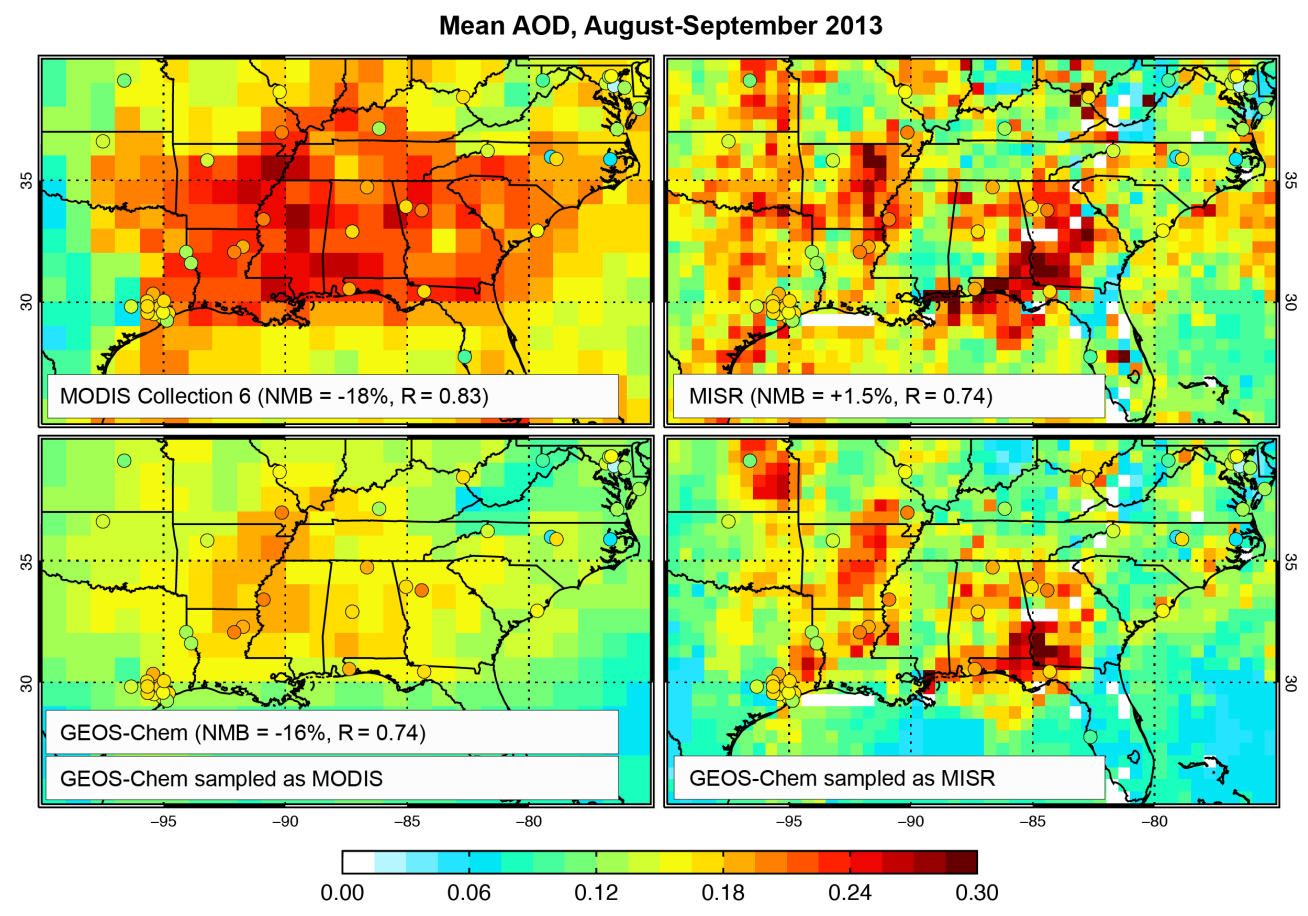

Figure 9. Mean aerosol optical depths (AODs) over the southeast US during SEAC ${ }^{4}$ RS (August-September 2013). AERONET data are shown as circles and are the same in all panels. The top panels show MODIS and MISR satellite observations with comparison statistics to AERONET (correlation coefficients, numerical mean biases or NMBs of collocated observations in time and space). The bottom panels show GEOS-Chem model values sampled at the same locations and times as the satellite retrievals. The noise in the MISR panels reflects infrequent sampling (9-day return time, compared to 1-day for MODIS). The negative NMB for the MODIS data reflects occasional retrievals of negative AOD.

\section{Aerosol extinction and optical depth}

We turn next to light extinction measurements onboard the DC-8 to better understand the relationship between the vertical profiles of aerosol mass (Sect. 4) and AOD. Aerosol extinction coefficients were measured on the SEAC ${ }^{4} \mathrm{RS}$ aircraft remotely above and below the aircraft by the NASA HSRL and at the altitude of the aircraft by the in situ NOAA cavity ringdown spectrometer (CRDS; Langridge et al., 2011). Figure 8 compares the two measurements, both at $532 \mathrm{~nm}$, with GEOS-Chem. Though the two instruments sampled different regions of the atmosphere at any given time, the mission median profiles are similar. The exception is between 2 and $4 \mathrm{~km}$, where the HSRL extinction coefficient is lower. The shapes of the vertical extinction profiles are consistent with aerosol mass (Fig. 6). The fraction of total column aerosol extinction below $3 \mathrm{~km}$ is $93 \%$ for the HSRL data $(91 \%$ in GEOS-Chem when sampled at the observation times) and $85 \%$ for the CRDS data (85\% in GEOS-Chem). Almost all of the column extinction is below $5 \mathrm{~km}(94 \%$ for the CRDS and $93 \%$ for GEOS-Chem). Integrated up to the ceiling of the DC-8 aircraft, the median AODs from HSRL and the CRDS are 0.14 and 0.17 , respectively $(0.12$ and 0.15 for GEOS-Chem).
Figure 9 shows maps of the mean AOD over the southeast US in August-September 2013 as measured by AERONET, MISR, MODIS on the Aqua satellite, and simulated by GEOS-Chem. The model is sampled at the local satellite overpass times (1030 for MISR and 1330 for MODIS). We use the Version 31 Level 3 product from MISR (gridded averages at $0.5^{\circ} \times 0.5^{\circ}$ resolution) and the Collection 6 Level 3 product from MODIS (gridded averages at $1^{\circ} \times 1^{\circ}$ resolution). We exclude MODIS observations with cloud fraction greater than 0.5 or AOD greater than 1.5 to account for cloud contamination and sensor saturation as in Ford and Heald (2013). We use the Level 2 cloud-filtered daytime average AERONET observations, which can be viewed as a reference measurement.

Comparison of daily collocated MODIS and MISR retrievals with AERONET observations shows high correlation and little bias (statistics inset in Fig. 9). These statistics were calculated only when there are collocated and corresponding data for both AERONET and the satellite retrieval, whereas Fig. 9 shows the spatial average of all available data during August-September 2013. MODIS shows a broad maximum over the southeast US that corresponds well with observed $\mathrm{PM}_{2.5}$ in Fig. 3. There is greater heterogeneity in the MISR average due to sparse sampling. GEOS-Chem captures the spatial pattern of the regional AOD enhancement when 


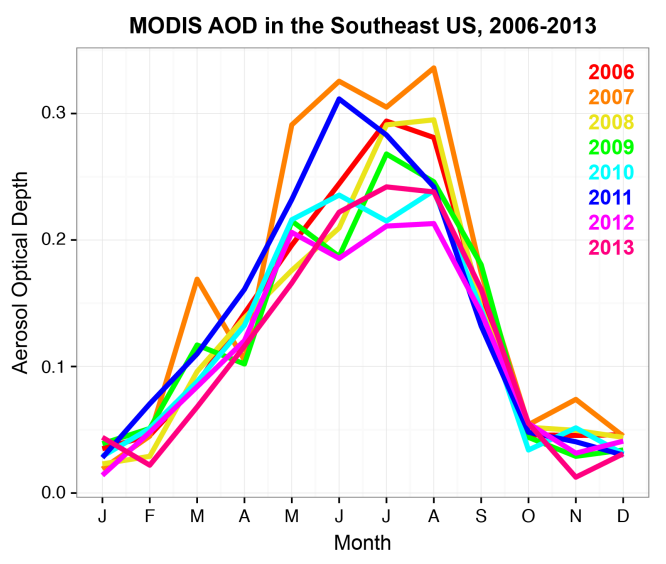

Figure 10. Seasonal variation of MODIS AOD over the southeast US for 2006-2013. The southeast US domain is as defined in Fig. 2.

sampled with the different retrievals and underestimates the magnitude by $16 \%$ (NMB relative to AERONET), consistent with the underestimate of the aircraft aerosol extinction data (including the NASA Ames 4STAR sun photometer, Supplement). The model underestimates AOD (NMB) by $28 \%$, relative to MODIS and by $8 \%$, relative to MISR.

\section{The aerosol seasonal cycle}

As pointed out in the introduction, there has been considerable interest in interpreting the aerosol seasonal cycle over the southeast US and the difference in seasonal amplitude between AOD and surface $\mathrm{PM}_{2.5}$ (Goldstein et al., 2009; Ford and Heald, 2013). Figure 10 shows MODIS monthly average AOD over the southeast US for 2006-2013. The observed AOD in 2013 shows a seasonal cycle consistent with previous years. There has been a general decline in the seasonal amplitude over 2006-2013 driven by a negative summertime trend, with 2011 being anomalous due to high fire activity. The same long-term decrease and 2011 anomaly are seen in the surface $\mathrm{PM}_{2.5}$ data (Fig. 1). Examination of Fig. 10 reveals that the entirety of the seasonal decrease from summer to winter takes place as a sharp transition in the AugustOctober window, in all years.

We analyzed the causes of this August-October transition using the GEOS-Chem simulation of the SEAC ${ }^{4} \mathrm{RS}$ period. Figure 11a shows the time series of daily median AOD from AERONET, GEOS-Chem sampled at the times and locations of the AERONET observations, and MODIS over the southeast US. The difference between AERONET and MODIS can be explained by differences in sampling (they otherwise correspond well with each other, see Sect. 6). Observations through early September show large oscillations with a 7-10day period driven by frontal passages. These are well reproduced by the model. The observed AODs then fall sharply in mid-September and again, this is well reproduced by GEOS-

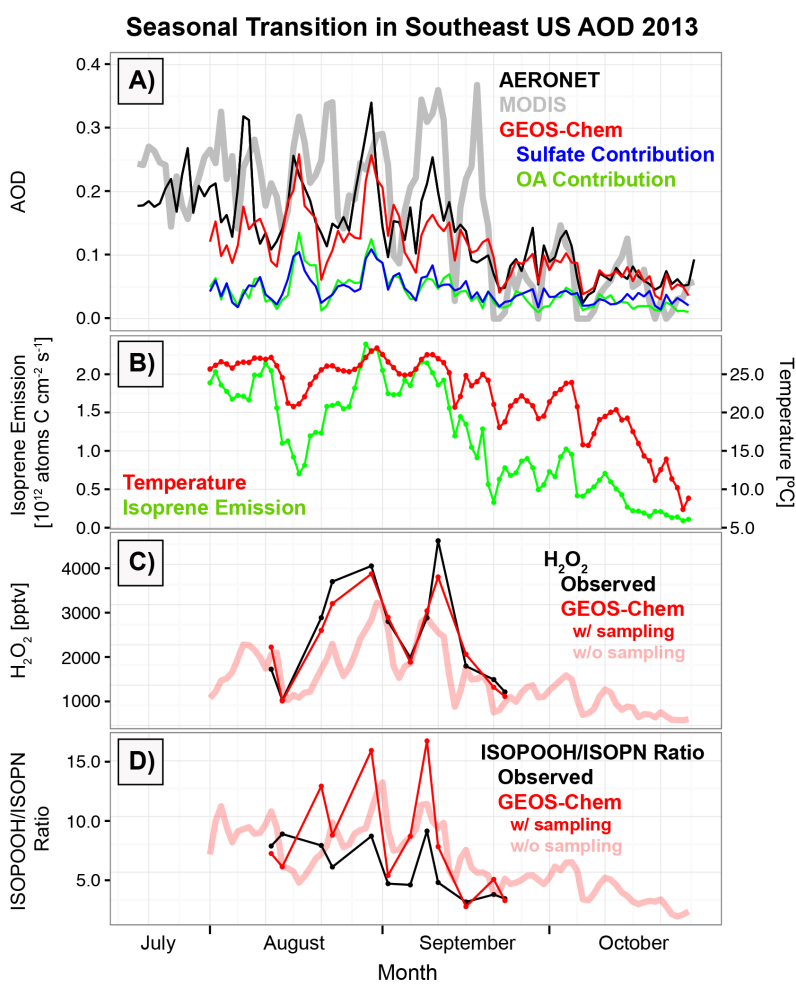

Figure 11. Seasonal transition of aerosol optical depth (AOD) and related variables over the southeast US in August-October 2013. (a) AODs measured by MODIS and AERONET, and GEOSChem values sampled at AERONET times and locations with simulated contributions from sulfate and OA. (b) 24-hour average MEGAN2.1 isoprene emissions and GEOS-FP surface air temperatures. (c) $\mathrm{H}_{2} \mathrm{O}_{2}$ concentrations measured from the aircraft below $1 \mathrm{~km}$ altitude and simulated by GEOS-Chem sampled at the times and locations of the observations. Each data point represents the median value over the southeast US for an individual flight. GEOSChem $\mathrm{H}_{2} \mathrm{O}_{2}$ concentrations averaged over the entire region (i.e., without sampling along the flight tracks) are shown separately and extend into October. (d) Same as (c) but for the molar ratio of isoprene peroxides (ISOPOOH) to isoprene nitrates (ISOPN). The southeast US domain is as defined in Fig. 2.

Chem. The successful simulation of the August-October seasonal transition implies that we can use the model to understand the causes of this transition. Figure 11 also shows the sulfate and OA contributions to GEOS-Chem AOD. Sulfate aerosol contributes as much to column light extinction as OA, despite lower concentrations, due to its higher mass extinction efficiency. Both the sulfate and OA contributions to AOD fall during the seasonal transition.

We find that the sharp drops in sulfate and OA concentrations over August-October are due to two factors. The first is a decline in isoprene and monoterpene emissions due to cooler surface temperatures and leaf senescence (Fig. 11b). The second is a transition in the photochemical regime as UV radiation sharply declines (Kleinman, 1991; Jacob et al., 
1995), depleting $\mathrm{OH}$ and $\mathrm{H}_{2} \mathrm{O}_{2}$ (panel c) and hence sulfate formation.

The seasonal transition in photochemical regime also involves a shift from a low-NO to a high-NO chemical regime (Kleinman, 1991; Jacob et al., 1995). This would affect the SOA yield (Marais et al., 2015), though this is not represented in the current GEOS-Chem simulation. Figure 11d shows the ratio of isoprene hydroperoxides (ISOPOOH) to isoprene nitrate (ISOPN) concentrations measured in the PBL during SEAC ${ }^{4}$ RS by the Caltech CIMS (Crounse et al., 2006; St. Clair et al., 2010) and simulated by GEOS-Chem. ISOPOOH is formed under low-NO conditions, while ISOPN is formed under high-NO conditions. Both observations and the model show a decline in the ISOPOOH / ISOPN concentration ratio over the course of SEAC ${ }^{4} \mathrm{RS}$, with the model showing extended decline into October. If the SOA yield is higher under low-NO conditions (Kroll et al., 2005, 2006; Xu et al., 2014) then this would also contribute to the seasonal decline in OA.

We have thus explained the seasonality of AOD as driven by aerosol sources. Previous studies have pointed out that surface $\mathrm{PM}_{2.5}$ in the southeast US has much weaker seasonality than AOD, and observed $\mathrm{PM}_{2.5}$ in 2013 had no significant seasonality (Fig. 12, top panel). This difference in the amplitude of the seasonal cycle between $\mathrm{PM}_{2.5}$ and AOD is simulated to some extent by GEOS-Chem, as shown in Fig. 12. It is driven in GEOS-Chem by the seasonal variation in ML height (middle panel of Fig. 12), dampening the seasonal cycle of $\mathrm{PM}_{2.5}$ by reducing ventilation in winter. The AOD in GEOS-Chem is lower than observed in summer and higher in winter, so that the seasonality is weaker than observed (a factor of 2 compared to an observed factor of 3-4). The summer underestimate is consistent with the aircraft observations, as discussed previously. The winter overestimate could reflect seasonal error in model aerosol sources or optical properties. These model biases aside, one would expect the seasonal variation of boundary layer mixing to dampen the seasonal variation of surface $\mathrm{PM}_{2.5}$ relative to AOD, as is found in the observations and in the model.

\section{Conclusions}

We have used a large ensemble of surface, aircraft, and satellite observations during the SEAC ${ }^{4} \mathrm{RS}$ field campaign over the southeast US in August-September 2013 to better understand (1) the sources of sulfate and organic aerosol (OA) in the region; (2) the relationship between the aerosol optical depth (AOD) measured from space and the fine particulate matter concentration $\left(\mathrm{PM}_{2.5}\right)$ measured at the surface; and (3) the seasonal aerosol cycle and the apparent inconsistency between satellite and surface measurements. Our work used the GEOS-Chem global chemical transport model (CTM) with $0.25^{\circ} \times 0.3125^{\circ}\left(\sim 25 \times 25 \mathrm{~km}^{2}\right)$ horizontal resolution

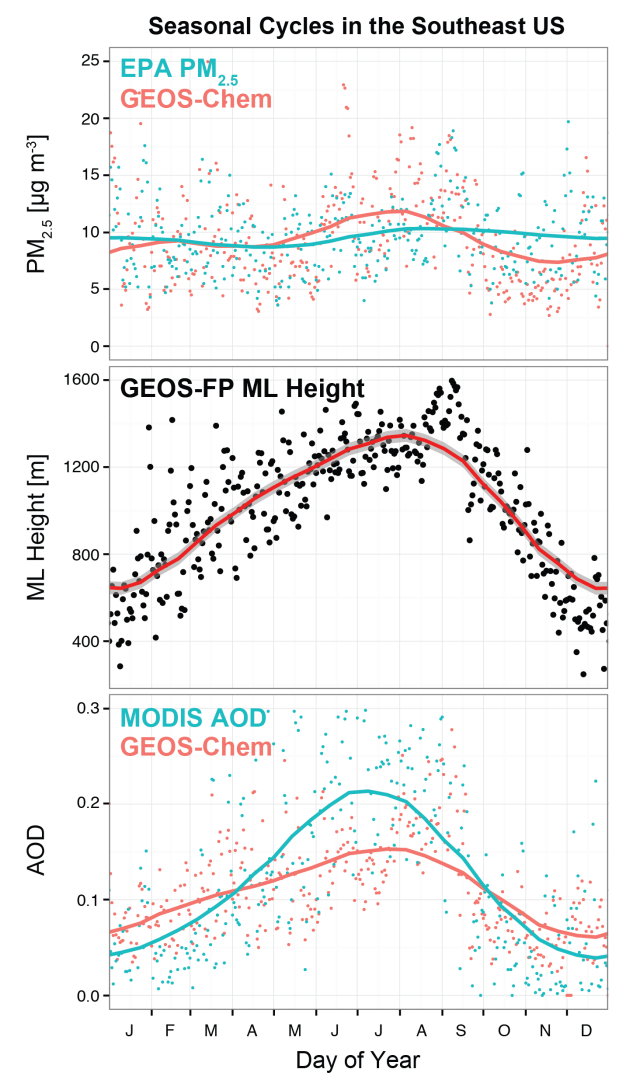

Figure 12. Seasonal aerosol cycle in the southeast US in 2013. Top: daily mean EPA and GEOS-Chem $\mathrm{PM}_{2.5}$. Middle: daily maximum mixed layer height from GEOS-FP with $40 \%$ downward correction applied year-round as in GEOS-Chem (see Sect. 2). Bottom: daily mean AOD from MODIS and GEOS-Chem. GEOS-Chem results in this figure are from the coarse-resolution $\left(4^{\circ} \times 5^{\circ}\right)$ global simulation for 2013. Smoothed curves are calculated using a low-pass filter. All values are averaged over the southeast US as defined in Fig. 2.

over North America as an integrative platform to compare and interpret the ensemble of observations.

$\mathrm{PM}_{2.5}$ surface observations are fairly homogenous across the southeast US, reflecting regional coherence in stagnation, mixing, and ventilation. Sulfate and OA account for the bulk of $\mathrm{PM}_{2.5}$. GEOS-Chem simulates sulfate without bias but this requires uncertain consideration of $\mathrm{SO}_{2}$ oxidation by stabilized Criegee intermediates to account for $30 \%$ of sulfate production in the southeast US. We reproduce the major features of OA observations with a simple parameterization, assuming irreversible condensation of low-volatility VOC oxidation products. Marais et al. (2015) show that the default SOA mechanism in GEOS-Chem, based on reversible partitioning of semivolatile products of VOC oxidation (Pye et al., 2010), underestimates isoprene SOA formation by a factor of 3 in the SEAC ${ }^{4} \mathrm{RS}$ observations. Our OA simulation bias is $+14 \%$ relative to CSN sites and $+66 \%$ relative to IMPROVE sites but the IMPROVE data may be too low. OA 
in the model originates from biogenic isoprene (40\%) and monoterpenes $(20 \%)$, anthropogenic sources $(30 \%)$, and open fires $(10 \%)$. Marais et al. (2015) present an improved GEOS-Chem simulation of isoprene SOA in SEAC ${ }^{4} \mathrm{RS}$ using an aqueous-phase mechanism with irreversible uptake coupled to the gas-phase isoprene oxidation cascade and separating the contributions from the high-NO and low-NO pathways. This mechanism provides in particular a successful simulation of observations for the OA-formaldehyde relationship and for the concentration of SOA formed from isoprene epoxides.

Aircraft vertical profiles show that $60 \%$ of the aerosol column mass is in the mixed layer (ML), $25 \%$ is in the convective cloud layer (CCL), and $15 \%$ is in the free troposphere (FT). This is well reproduced in GEOS-Chem. OA accounts for $65 \%$ of the aerosol column mass in the observations and in the model. The successful simulation of OA vertical profiles argues against a large OA source in the free troposphere other than PBL ventilation. Occasional fire and dust plumes were observed in the free troposphere but have little impact on temporal averages.

The extent of neutralization of sulfate aerosol over the southeast US $\left(f=\left[\mathrm{NH}_{4}^{+}\right] /\left(2\left[\mathrm{SO}_{4}^{2-}\right]+\left[\mathrm{NO}_{3}^{-}\right]\right)\right)$is observed to be in the range $0.49-0.68 \mathrm{~mol} \mathrm{~mol}^{-1}$ for the different data sets, despite an excess of ammonia being present. This is inconsistent with thermodynamic equilibrium and with the observation of a 2003-2013 decline in ammonium aerosol concentrations paralleling that of sulfate. We hypothesize that the departure from equilibrium is correlated with OA, as supported by laboratory findings by Liggio et al. (2011) that organic particle material may impede ammonia uptake by sulfate aerosol. This may have important implications for aerosol hygroscopicity and chemistry.

The vertical profile of aerosol light extinction measured from the aircraft follows closely that of aerosol mass. GEOSChem has a $\sim 16 \%$ low bias in aerosol extinction compared to these observations and simulates the vertical profile correctly. Sulfate accounts for as much of the column light extinction as OA, despite lower mass concentrations. Evaluation of collocated MODIS and MISR AOD retrievals with AERONET shows excellent agreement. GEOS-Chem is $16 \%$ too low compared to AERONET and 7-28\% too low compared to MODIS and MISR, consistent with its bias relative to the aircraft extinction data. We thus find reasonable agreement between AODs measured from space and from the surface, aircraft aerosol extinction and mass profiles, and surface $\mathrm{PM}_{2.5}$ measurements, the largest discrepancy being between different measurements of OA.

We find that the previously reported summer-to-winter decrease in MODIS AOD data over the southeast US is driven by a sharp August-to-October transition, in all years. This seasonal transition is well captured by GEOS-Chem where it is caused by declines in both sulfate and OA. Biogenic emissions of isoprene and monoterpenes shut down during this time period due to lower temperatures and leaf senescence, and rapidly declining UV radiation suppresses $\mathrm{SO}_{2}$ oxidation by $\mathrm{OH}$ and $\mathrm{H}_{2} \mathrm{O}_{2}$. The seasonal decline of $\mathrm{UV}$ radiation also suppresses the low-NO pathway of isoprene oxidation, which may be associated with larger OA yields than the highNO pathway.

Previous studies have pointed out an apparent inconsistency between the large seasonal variation of AOD measured from space and the much weaker seasonal variation of $\mathrm{PM}_{2.5}$ measured at the surface (Goldstein et al., 2009; Ford and Heald, 2013). We find that this can be explained at least in part by the seasonal trend in boundary layer ventilation, offsetting the effect of decreased wintertime PM sources on the surface concentrations. Overall our results show that measured AODs from space are consistent with measurements of $\mathrm{PM}_{2.5}$ air quality in the southeast US. This implies that satellite measurements can reliably be used to infer $\mathrm{PM}_{2.5}$ if a good CTM representation of PBL mixing and ventilation is available.

\section{The Supplement related to this article is available online at doi:10.5194/acp-15-10411-2015-supplement.}

Acknowledgements. We are grateful to the entire NASA SEAC ${ }^{4} \mathrm{RS}$ team for their help in the field. We thank Aaron van Donkelaar, Eloise Marais, Loretta Mickley, Randall Martin, Chuck Brock, Ann Dillner, Ralph Kahn, Armin Sorooshian, Tran Nguyen, and Jenny Hand for helpful discussions and Sajeev Philip for assistance with downloading meteorological fields. We also thank Jack Dibb, Bruce Anderson and the LARGE team, Phil Russell, Jens Redemann and the 4STAR team, and Greg Huey for the data shown in the Supplement. This work was funded by the NASA Tropospheric Chemistry Program and by a Department of Energy Office of Science Graduate Fellowship to PSK made possible in part by the American Recovery and Reinvestment Act of 2009, administered by ORISE-ORAU under contract no. DE-AC05-06OR23100. P. Campuzano-Jost and J. L. Jimenez were supported by NASA NNX12AC03G and NSF AGS-1243354/1360834. K. D. Froyd and J. Liao are supported by NASA grant NNH12AT29I from the Upper Atmosphere Research Program, Radiation Sciences Program, and Tropospheric Chemistry Program, and by NOAA base funding. D. B. Millet acknowledges support from NSF (Grant \#1148951). P. O. Wennberg, J. D. Crounse, J. M. St. Clair, and A. P. Teng acknowledge support from NASA (NNX12AC06G and NNX14AP46G). We thank the US EPA for providing the 2010 North American emission inventory. The inventory is intended for research purposes and was developed for Phase 2 of the Air Quality Model Evaluation International Initiative (AQMEII) using information from the 2008-based modeling platform as a starting point. A technical document describing the 2008-based 2007v5 modeling platform can be found at http://epa.gov/ttn/chief/emch/2007v5/2007v5_2020base_ EmisMod_TSD_13dec2012.pdf. A report on the 2008 NEI can be found at www.epa.gov/ttn/chief/net/2008report.pdf. GEOS-Chem 
is managed by the Harvard University Atmospheric Chemistry Modeling Group with support from the NASA Atmospheric Composition Modeling and Analysis Program. The GEOS-FP data used in this study were provided by the Global Modeling and Assimilation Office (GMAO) at NASA Goddard Space Flight Center.

Edited by: K. Tsigaridis

\section{References}

Alston, E. J., Sokolik, I. N., and Kalashnikova, O. V.: Characterization of atmospheric aerosol in the US Southeast from ground- and space-based measurements over the past decade, Atmos. Meas. Tech., 5, 1667-1682, doi:10.5194/amt-5-1667-2012, 2012.

Attwood, A. R., Washenfelder, R. A., Brock, C. A., Hu, W., Baumann, K., Campuzano-Jost, P., Day, D. A., Edgerton, E. S., Murphy, D. M., Palm, B. B., McComiskey, A., Wagner, N. L., de Sa, S. S., Ortega, A., Martin, S. T., Jimenez, J. L., and Brown, S. S.: Trends in sulfate and organic aerosol mass in the Southeast U.S.: Impact on aerosol optical depth and radiative forcing, Geophys. Res. Lett., 41, 7701-7709, doi:10.1002/2014GL061669, 2014.

Baasandorj, M., Millet, D. B., Hu, L., Mitroo, D., and Williams, B. J.: Measuring acetic and formic acid by proton-transferreaction mass spectrometry: sensitivity, humidity dependence, and quantifying interferences, Atmos. Meas. Tech., 8, 13031321, doi:10.5194/amt-8-1303-2015, 2015.

Barsanti, K. C., Carlton, A. G., and Chung, S. H.: Analyzing experimental data and model parameters: implications for predictions of SOA using chemical transport models, Atmos. Chem. Phys., 13, 12073-12088, doi:10.5194/acp-13-12073-2013, 2013.

Blanchard, C. L., Hidy, G. M., Tanenbaum, S., Edgerton, E., Hartsell, B., and Jansen, J.: Carbon in southeastern US aerosol particles: empirical estimates of secondary organic aerosol formation, Atmos. Environ., 42, 6710-6720, doi:10.1016/j.atmosenv.2008.04.011, 2008.

Blanchard, C. L., Hidy, G. M., Tanenbaum, S., Edgerton, E. S., and Hartsell, B. E.: The Southeastern Aerosol Research and Characterization (SEARCH) study: Temporal trends in gas and PM concentrations and composition, 1999-2010, J. Air Waste Manage., 63, 247-259, doi:10.1080/10962247.2012.748523, 2013.

Boy, M., Mogensen, D., Smolander, S., Zhou, L., Nieminen, T., Paasonen, P., Plass-Dülmer, C., Sipilä, M., Petäjä, T., Mauldin, L., Berresheim, H., and Kulmala, M.: Oxidation of $\mathrm{SO}_{2}$ by stabilized Criegee intermediate $(\mathrm{sCI})$ radicals as a crucial source for atmospheric sulfuric acid concentrations, Atmos. Chem. Phys., 13, 3865-3879, doi:10.5194/acp-13-3865-2013, 2013.

Boys, B. L., Martin, R. V., van Donkelaar, A., MacDonell, R. J., Hsu, N. C., Cooper, M. J., Yantosca, R. M., Lu, Z., Streets, D. G., Zhang, Q., and Wang, S. W.: Fifteen-year global time series of satellite-derived fine particulate matter, Environ. Sci. Technol., 48, 11109-11118, doi:10.1021/es502113p, 2014.

Budisulistiorini, S. H., Canagaratna, M. R., Croteau, P. L., Marth, W. J., Baumann, K., Edgerton, E. S., Shaw, S. L., Knipping, E. M., Worsnop, D. R., Jayne, J. T., Gold, A., and Surratt, J. D.: Real-time continuous characterization of secondary organic aerosol derived from isoprene epoxydiols in downtown Atlanta,
Georgia, using the Aerodyne Chemical Speciation Monitor, Environ. Sci. Technol., 47, 5686-5694, doi:10.1021/es400023n, 2013.

Campuzano-Jost, P., Palm, B., Day, D., Hu, W., Ortega, A., Jimenez, J., Liao, J., Froyd, K., Pollack, I., Peischl, J., Ryerson, T., St. Clair, J., Crounse, J., Wennberg, P., Mikoviny, T., Wisthaler, A., Ziemba, L., and Anderson, B.: Secondary organic aerosol (SOA) derived from isoprene epoxydiols: Insights into formation, aging, and distribution over the continental US from the DC3 and SEAC4RS campaigns, Abstract A33M-02 presented at 2014 Fall Meeting, 15-19 December, AGU, San Francisco, Calif., 2014.

Canagaratna, M. R., Jayne, J. T., Jimenez, J. L., Allan, J. D., Alfarra, M. R., Zhang, Q., Onasch, T. B., Drewnick, F., Coe, H., Middlebrook, A., Delia, A., Williams, L. R., Trimborn, A. M., Northway, M. J., DeCarlo, P. F., Kolb, C. E., Davidovits, P., and Worsnop, D. R.: Chemical and microphysical characterization of ambient aerosols with the aerodyne aerosol mass spectrometer, Mass Spectrom. Rev., 26, 185-222, doi:10.1002/mas.20115, 2007.

Canagaratna, M. R., Jimenez, J. L., Kroll, J. H., Chen, Q., Kessler, S. H., Massoli, P., Hildebrandt Ruiz, L., Fortner, E., Williams, L. R., Wilson, K. R., Surratt, J. D., Donahue, N. M., Jayne, J. T., and Worsnop, D. R.: Elemental ratio measurements of organic compounds using aerosol mass spectrometry: characterization, improved calibration, and implications, Atmos. Chem. Phys., 15, 253-272, doi:10.5194/acp-15-253-2015, 2015.

Carlton, A. G., Pinder, R. W., Bhave, P. K., and Pouliot, G. A.: To what extent can biogenic SOA be controlled?, Environ. Sci. Technol., 44, 3376-3380, doi:10.1021/es903506b, 2010.

Chan, A. W. H., Chan, M. N., Surratt, J. D., Chhabra, P. S., Loza, C. L., Crounse, J. D., Yee, L. D., Flagan, R. C., Wennberg, P. O., and Seinfeld, J. H.: Role of aldehyde chemistry and $\mathrm{NO}_{x}$ concentrations in secondary organic aerosol formation, Atmos. Chem. Phys., 10, 7169-7188, doi:10.5194/acp-10-7169-2010, 2010.

Chao, W., Hsieh, J.-T., Chang, C.-H., and Lin, J. J.: Direct kinetic measurement of the reaction of the simplest Criegee intermediate with water vapor, Science, 347, 751-754, doi:10.1126/science.1261549, 2015.

Chen, G., Ziemba, L. D., Chu, D. A., Thornhill, K. L., Schuster, G. L., Winstead, E. L., Diskin, G. S., Ferrare, R. A., Burton, S. P., Ismail, S., Kooi, S. A., Omar, A. H., Slusher, D. L., Kleb, M. M., Reid, J. S., Twohy, C. H., Zhang, H., and Anderson, B. E.: Observations of Saharan dust microphysical and optical properties from the Eastern Atlantic during NAMMA airborne field campaign, Atmos. Chem. Phys., 11, 723-740, doi:10.5194/acp11-723-2011, 2011.

Chin, M. and Jacob, D. J.: Anthropogenic and natural contributions to tropospheric sulfate: A global model analysis, J. Geophys. Res., 101, 18691-18699, doi:10.1029/96JD01222, 1996.

Chow, J. C., Watson, J. G., Chen, L.-W. A., Rice, J., and Frank, N. H.: Quantification of $\mathrm{PM}_{2.5}$ organic carbon sampling artifacts in US networks, Atmos. Chem. Phys., 10, 5223-5239, doi:10.5194/acp-10-5223-2010, 2010.

Crawford, J. H. and Pickering, K. E.: DISCOVER-AQ: Advancing strategies for air quality observations in the next decade, Environ. Manage., 4-7, 2014.

Crounse, J. D., McKinney, K. A., Kwan, A. J., and Wennberg, P. O.: Measurement of gas-phase hydroperoxides by chemi- 
cal ionization mass spectrometry, Anal. Chem., 78, 6726-6732, doi:10.1021/ac0604235, 2006.

Cubison, M. J., Ortega, A. M., Hayes, P. L., Farmer, D. K., Day, D., Lechner, M. J., Brune, W. H., Apel, E., Diskin, G. S., Fisher, J. A., Fuelberg, H. E., Hecobian, A., Knapp, D. J., Mikoviny, T., Riemer, D., Sachse, G. W., Sessions, W., Weber, R. J., Weinheimer, A. J., Wisthaler, A., and Jimenez, J. L.: Effects of aging on organic aerosol from open biomass burning smoke in aircraft and laboratory studies, Atmos. Chem. Phys., 11, 12049-12064, doi:10.5194/acp-11-12049-2011, 2011.

Darmenov, A. and da Silva, A.: The Quick Fire Emissions Dataset (QFED) - Documentation of versions 2.1, 2.2 and 2.4, NASA Technical Report Series on Global Modeling and Data Assimilation, NASA TM-2013-104606, 32, 183 pp., Draft Document $(12939 \mathrm{kB}), 2013$.

de Gouw, J. A. and Jimenez, J. L.: Organic aerosols in the Earth's atmosphere, Environ. Sci. Technol., 43, 7614-7618, doi:10.1021/es9006004, 2009.

Dibb, J. E., Talbot, R. W., Scheuer, E. M., Seid, G., Avery, M. A., and Singh, H. B.: Aerosol chemical composition in Asian continental outflow during the TRACE-P campaign: comparison with PEM-West B, J. Geophys. Res., 108, 8815, doi:10.1029/2002JD003111, 2003.

Dillner, A. M., Phuah, C. H., and Turner, J. R.: Effects of post-sampling conditions on ambient carbon aerosol filter measurements, Atmos. Environ., 43, 5937-5943, doi:10.1016/j.atmosenv.2009.08.009, 2009.

Diner, D. J., Braswell, B. H., Davies, R., Gobron, N., Hu, J., Jin, Y., Kahn, R. A., Knyazikhin, Loeb, N., Muller, J.P., Nolin, A. W., Pinty, B., Schaaf, C. B., Seiz, G., and Stroeve, J.: The value of multiangle measurements for retrieving structurally and radiatively consistent properties of clouds, aerosols, and surfaces, Remote Sens. Environ., 97, 495-518, doi:10.1016/j.rse.2005.06.006, 2005.

Docherty, K. S., Stone, E. A., Ulbrich, I. M., DeCarlo, P. F., Snyder, D. C., Schauer, J. J., Peltier, R. E., Weber, R. J., Murphy, S. M., Seinfeld, J. H., Grover, B. D., Eatough, D. J., and Jimenez, J. L.: Apportionment of primary and secondary organic aerosols in Southern California during the 2005 Study of Organic Aerosols in Riverside (SOAR-1), Environ, Sci. Technol., 42, 7655-7662, doi:10.1021/es8008166, 2008.

Donahue, N. M., Robinson, A. L., Stanier, C. O., and Pandis, S. N.: Coupled partitioning, dilution, and chemical aging of semivolatile organics, Environ. Sci. Technol., 40, 2635-2643, doi:10.1021/es052297c, 2006.

Drury, E., Jacob, D. J., Spurr, R. J. D., Wang, J., Shinozuka, Y., Anderson, B. E., Clarke, A. D., Dibb, J., McNaughton, C., and Weber, R.: Synthesis of satellite (MODIS), aircraft (ICARTT), and surface (IMPROVE, EPA-AQS, AERONET) aerosol observations over eastern North America to improve MODIS aerosol retrievals and constrain surface aerosol concentrations and sources, J. Geophys. Res., 115, D14204, doi:10.1029/2009JD012629, 2010.

Eddingsaas, N. C., VanderVelde, D. G., and Wennberg, P. O.: Kinetics and products of the acid-catalyzed ring-opening of atmospherically relevant butyl epoxy alcohols, J. Phys. Chem. A, 114, 8106-8113, doi:10.1021/jp103907c, 2010.
Edgerton, E. S. and the SOAS science team: First look at ${ }^{14} \mathrm{C}$ data during the Centreville, AL SOAS campaign, presented at the SAS Data Workshop, 31 March-2 April, Boulder, Co., 2014.

Edgerton, E. S., Hartsell, B. E., Saylor, R. D., Jansen, J. J., Hansen, D. A., and Hidy, G. M.: The Southeastern Aerosol Research and Characterization Study: Part II. Filter-based measurements of fine and coarse particulate matter mass and composition, J. Air Waste Manage., 52, 1527-1542, doi:10.1080/10473289.2005.10464744, 2005.

Ervens, B., Turpin, B. J., and Weber, R. J.: Secondary organic aerosol formation in cloud droplets and aqueous particles (aqSOA): a review of laboratory, field and model studies, Atmos. Chem. Phys., 11, 11069-11102, doi:10.5194/acp-1111069-2011, 2011.

Fairlie, T. D., Jacob, D. J., and Park, R. J.: The impact of transpacific transport of mineral dust in the United States, Atmos. Environ., 41, 1251-1266, doi:10.1016/j.atmosenv.2006.09.048, 2007.

Fischer, E. V., Jacob, D. J., Yantosca, R. M., Sulprizio, M. P., Millet, D. B., Mao, J., Paulot, F., Singh, H. B., Roiger, A., Ries, L., Talbot, R.W., Dzepina, K., and Pandey Deolal, S.: Atmospheric peroxyacetyl nitrate (PAN): a global budget and source attribution, Atmos. Chem. Phys., 14, 2679-2698, doi:10.5194/acp-142679-2014, 2014.

Fisher, J. A., Jacob, D., Travis, K., Cohen, R., Fried, A., Hanisco, T., Mao, J., Wennberg, P., Crounse, J., St. Clair, J., Teng, A., Wisthaler, A., Mikoviny, T., Jimenez, J., Campuzano-Jost, P., Kim., P., Marais, E., Paulot, F., Yu, K., Zhu, L., Yantosca, R., and Sulprizio, M.: Isoprene nitrate chemistry in the Southeast US: Constraints from GEOS-Chem and SEAC ${ }^{4} \mathrm{RS}$, presented at the SEAC ${ }^{4}$ RS Science Team Meeting, 28 April-1 May, Pasadena, Calif., 2015.

Ford, B. and Heald, C. L.: Aerosol loading in the Southeastern United States: reconciling surface and satellite observations, Atmos. Chem. Phys., 13, 9269-9283, doi:10.5194/acp-13-92692013, 2013.

Fountoukis, C. and Nenes, A.: ISORROPIA II: a computationally efficient thermodynamic equilibrium model for $\mathrm{K}^{+}$$\mathrm{Ca}^{2+}-\mathrm{Mg}^{2+}-\mathrm{NH}_{4}^{+}-\mathrm{Na}^{+}-\mathrm{SO}_{4}^{2-}-\mathrm{NO}_{3}^{-}-\mathrm{Cl}^{-}-\mathrm{H}_{2} \mathrm{O}$ aerosols, Atmos. Chem. Phys., 7, 4639-4659, doi:10.5194/acp-7-4639-2007, 2007.

Froyd, K. D., Murphy, S. M., Murphy, D. M., de Gouw, J. A., Eddingsaas, N. C., and Wennberg P. O.: Contribution of isoprenederived organosulfates to free tropospheric aerosol mass, P. Natl. Acad. Sci., 107, 21360-21365, doi:10.1073/pnas.1012561107, 2010.

Fu, T. M., Jacob, D. J., and Heald, C. L.: Aqueous-phase reactive uptake of dicarbonyls as a source of organic aerosol over eastern North America, Atmos. Environ., 43, 1814-1822, doi:10.1016/j.atmosenv.2008.12.029, 2009.

Goldstein, A. H., Koven, C. D., Heald, C. L., and Fung, I. Y.: Biogenic carbon and anthropogenic pollutants combine to form a cooling haze over the southeastern United States, P. Natl. Acad. Sci., 106, 8835-8840, doi:10.1073/pnas.0904128106, 2009.

Guenther, A. B., Jiang, X., Heald, C. L., Sakulyanontvittaya, T., Duhl, T., Emmons, L. K., and Wang, X.: The Model of Emissions of Gases and Aerosols from Nature version 2.1 (MEGAN2.1): an extended and updated framework for modeling biogenic emissions, Geosci. Model Dev., 5, 1471-1492, doi:10.5194/gmd-51471-2012, 2012. 
Hair, J. W., Hostetler, C. A., Cook, A. L., Harper, D. B., Ferrare, R. A., Mack, T. L., Welch, W., Izquierdo, L. R., and Hovis, F. E.: Airborne High Spectral Resolution Lidar for profiling aerosol optical properties, Appl. Optics, 47, 6734-6752, doi:10.1364/AO.47.006734, 2008.

Hand, J. L., Schichtel, B. A., Pitchford, M., Malm, W. C., and Frank, N. H.: Seasonal composition of remote and urban fine particulate matter in the United States, J. Geophys. Res., 117, D05209, doi:10.1029/2011JD017122, 2012a.

Hand, J. L., Schichtel, B. A., Malm, W. C., and Pitchford, M. L.: Particulate sulfate ion concentration and $\mathrm{SO}_{2}$ emission trends in the United States from the early 1990s through 2010, Atmos. Chem. Phys., 12, 10353-10365, doi:10.5194/acp-1210353-2012, 2012b.

Hayes, P. L., Carlton, A. G., Baker, K. R., Ahmadov, R., Washenfelder, R. A., Alvarez, S., Rappenglück, B., Gilman, J. B., Kuster, W. C., de Gouw, J. A., Zotter, P., Prévôt, A. S. H., Szidat, S., Kleindienst, T. E., Offenberg, J. H., Ma, P. K., and Jimenez, J. L.: Modeling the formation and aging of secondary organic aerosols in Los Angeles during CalNex 2010, Atmos. Chem. Phys., 15, 5773-5801, doi:10.5194/acp-15-5773-2015, 2015.

Heald, C. L., Jacob, D. J., Turquety, S., Hudman, R. C., Weber, R. J., Sullivan, A. P., Peltier, R. E., Atlas, E. L., de Gouw, J. A., Warneke, C., Holloway, J. S., Neuman, J. A., Flocke, F. M., and Seinfeld, J. H.: Concentrations and sources of organic carbon aerosols in the free troposphere over North America, J. Geophys. Res., 111, D23S47, doi:10.1029/2006JD007705, 2006.

Heald, C. L., Coe, H., Jimenez, J. L., Weber, R. J., Bahreini, R., Middlebrook, A. M., Russell, L. M., Jolleys, M., Fu, T.-M., Allan, J. D., Bower, K. N., Capes, G., Crosier, J., Morgan, W. T., Robinson, N. H., Williams, P. I., Cubison, M. J., DeCarlo, P. F., and Dunlea, E. J.: Exploring the vertical profile of atmospheric organic aerosol: comparing 17 aircraft field campaigns with a global model, Atmos. Chem. Phys., 11, 12673-12696, doi:10.5194/acp-11-12673-2011, 2011.

Heald, C. L., Collett Jr., J. L., Lee, T., Benedict, K. B., Schwandner, F. M., Li, Y., Clarisse, L., Hurtmans, D. R., Van Damme, M., Clerbaux, C., Coheur, P.-F., Philip, S., Martin, R. V., and Pye, H. O. T.: Atmospheric ammonia and particulate inorganic nitrogen over the United States, Atmos. Chem. Phys., 12, 10295-10312, doi:10.5194/acp-12-10295-2012, 2012.

Henze, D. K. and Seinfeld, J. H.: Global secondary organic aerosol from isoprene oxidation, Geophys. Res. Lett., 33, L09812, doi:10.1029/2006GL025976, 2006.

Hermansson, E., Roldin, P., Rusanen, A., Mogensen, D., Kivekäs, N., Väänänen, R., Boy, M., and Swietlicki, E.: Biogenic SOA formation through gas-phase oxidation and gas-to-particle partitioning - a comparison between process models of varying complexity, Atmos. Chem. Phys., 14, 11853-11869, doi:10.5194/acp-1411853-2014, 2014.

Hidy, G. M., Blanchard, C. L., Baumann, K., Edgerton, E., Tanenbaum, S., Shaw, S., Knipping, E., Tombach, I., Jansen, J., and Walters, J.: Chemical climatology of the southeastern United States, 1999-2013, Atmos. Chem. Phys., 14, 11893-11914, doi:10.5194/acp-14-11893-2014, 2014.

Hodzic, A. and Jimenez, J. L.: Modeling anthropogenically controlled secondary organic aerosols in a megacity: a simplified framework for global and climate models, Geosci. Model Dev., 4, 901-917, doi:10.5194/gmd-4-901-2011, 2011.
Holben, B. N., Eck, T. F., Slutsker, I., Tanre, D., Buis, J. P., Setzer, A., Vermote, E., Reagan, J. A., Kaufman, Y. J., Nakajima, T., Lavenu, F., Jankowiak, I., and Smirnov, A.: AERONET - A federated instrument network and data archive for aerosol characterization, Remote Sens. Environ., 66, 1-16, doi:10.1016/S00344257(98)00031-5, 1998.

Hoyle, C. R., Boy, M., Donahue, N. M., Fry, J. L., Glasius, M., Guenther, A., Hallar, A. G., Huff Hartz, K., Petters, M. D., Petäjä, T., Rosenoern, T., and Sullivan, A. P.: A review of the anthropogenic influence on biogenic secondary organic aerosol, Atmos. Chem. Phys., 11, 321-343, doi:10.5194/acp-11-321-2011, 2011.

Hu, L., Millet, D. B., Baasandorj, M., Griffis, T. J., Turner, P., Helmig, D., Curtis, A. J., and Hueber, J.: Isoprene emissions and impacts over an ecological transition region in the US Upper Midwest inferred from tall tower measurements, J. Geophys. Res.-Atmos., 120, 3553-3571, doi:10.1002/2014JD022732, 2015.

Hu, W. W., Campuzano-Jost, P., Palm, B. B., Day, D. A., Ortega, A. M., Hayes, P. L., Krechmer, J. E., Chen, Q., Kuwata, M., Liu, Y. J., de Sá, S. S., Martin, S. T., Hu, M., Budisulistiorini, S. H., Riva, M., Surratt, J. D., St. Clair, J. M., Isaacman-Van Wertz, G., Yee, L. D., Goldstein, A. H., Carbone, S., Artaxo, P., de Gouw, J. A., Koss, A., Wisthaler, A., Mikoviny, T., Karl, T., Kaser, L., Jud, W., Hansel, A., Docherty, K. S., Robinson, N. H., Coe, H., Allan, J. D., Canagaratna, M. R., Paulot, F., and Jimenez, J. L.: Characterization of a real-time tracer for Isoprene Epoxydiolsderived Secondary Organic Aerosol (IEPOX-SOA) from aerosol mass spectrometer measurements, Atmos. Chem. Phys. Discuss., 15, 11223-11276, doi:10.5194/acpd-15-11223-2015, 2015.

$\mathrm{Hu}$, X., Waller, L. A., Lyapustin, A., Wang, Y., and Liu, Y.: 10year spatial and temporal trends of $\mathrm{PM}_{2.5}$ concentrations in the southeastern US estimated using high-resolution satellite data, Atmos. Chem. Phys., 14, 6301-6314, doi:10.5194/acp-14-63012014, 2014.

Hudman, R. C., Moore, N. E., Mebust, A. K., Martin, R. V., Russell, A. R., Valin, L. C., and Cohen, R. C.: Steps towards a mechanistic model of global soil nitric oxide emissions: implementation and space based-constraints, Atmos. Chem. Phys., 12, 7779-7795, doi:10.5194/acp-12-7779-2012, 2012.

Jacob, D. J., Horowitz, L. W., Munger, J. W., Heikes, B. G., Dickerson, R. R., Artz, R. S., and Keene, W. C.: Seasonal transition from $\mathrm{NO}_{x}$ - to hydrocarbon-limited conditions for ozone production over the eastern United States in September, J. Geophys. Res., 100, 9315-9324, doi:10.1029/94JD03125, 1995.

Jaeglé, L., Quinn, P. K., Bates, T. S., Alexander, B., and Lin, J.-T.: Global distribution of sea salt aerosols: new constraints from in situ and remote sensing observations, Atmos. Chem. Phys., 11, 3137-3157, doi:10.5194/acp-11-3137-2011, 2011.

Jenkin, M. E., Saunders, S. M., and Pilling, M. J.: The tropospheric degradation of volatile organic compounds: A protocol for mechanism development, Atmos. Environ., 31, 81-104, doi:10.1016/s1352-2310(96)00105-7, 1997.

Jimenez, J. L., Canagaratna, M. R., Donahue, N. M., Prevot, A. S. H., Zhang, Q., Kroll, J. H., DeCarlo, P. F., Allan, J. D., Coe, H., Ng, N. L., Aiken, A. C., Docherty, K. S., Ulbrich, I. M., Grieshop, A. P., Robinson, A. L., Duplissy, J., Smith, J. D., Wilson, K. R., Lanz, V. A., Hueglin, C., Sun, Y. L., Tian, J., Laaksonen, A., Raatikainen, T., Rautiainen, J., Vaattovaara, P., Ehn, M., Kulmala, M., Tomlinson, J. M., Collins, D. R., Cubison, M. 
J., Dunlea, E. J., Huffman, J. A., Onasch, T. B., Alfarra, M. R., Williams, P. I., Bower, K., Kondo, Y., Schneider, J., Drewnick, F., Borrmann, S., Weimer, S., Demerjian, K., Salcedo, D., Cottrell, L., Griffin, R., Takami, A., Miyoshi, T., Hatakeyama, S., Shimono, A., Sun, J. Y., Zhang, Y. M., Dzepina, K., Kimmel, J. R., Sueper, D., Jayne, J. T., Herndon, S. C., Trimborn, A. M., Williams, L. R., Wood, E. C., Middlebrook, A. M., Kolb, C. E., Baltensperger, U., and Worsnop, D. R.: Evolution of organic aerosols in the Atmosphere, Science, 326, 1525-1529, doi:10.1126/science.1180353, 2009.

Jolleys, M. D., Coe, H., McFiggans, G., Capes, G., Allan, J. D., Crosier, J., Williams, P. I., Allen, G., Bower, K. N., Jimenez, J. L., Russell, L. M., Grutter, M., and Baumgardner, D.: Characterizing the aging of biomass burning organic aerosol by use of mixing ratios: a meta-analysis of four regions, Environ. Sci. Technol., 46, 13093-13102, doi:10.1021/es302386v, 2012.

Kim, P. S., Jacob, D. J., Liu, X., Warner, J. X., Yang, K., Chance, K., Thouret, V., and Nedelec, P.: Global ozone-CO correlations from OMI and AIRS: constraints on tropospheric ozone sources, Atmos. Chem. Phys., 13, 9321-9335, doi:10.5194/acp-13-93212013, 2013.

Kleindienst, T. E., Jaoui, M., Lewandowski, M., Offenberg, J. H., Lewis, C. W., Bhave, P. V., and Edney, E. O.: Estimates of the contributions of biogenic and anthropogenic hydrocarbons to secondary organic aerosol at a southeastern US location, Atmos. Environ., 41, 8288-8300, doi:10.1016/j.atmosenv.2007.06.045, 2007.

Kleinman, L. I.: Seasonal dependence of boundary layer peroxide concentration: The low and high $\mathrm{NO}_{x}$ regimes, J. Geophys. Res., 96, 20721-20733, doi:10.1029/91JD02040, 1991.

Koepke P., Hess, M., Schult, I., and Shettle, E. P.: Global Aerosol Data Set, Max-Planck-Institut fur Meteorologie, Hamburg, 1997.

Kroll, J. H., Ng, N. L., Murphy, S. M., Flagan, R. C., and Seinfeld, J. H.: Secondary organic aerosol formation from isoprene photooxidation under high- $\mathrm{NO}_{x}$ conditions, Geophys. Res. Lett., 32, L18808, doi:10.1029/2005GL023637, 2005.

Kroll, J. H., Ng, N. L., Murphy, S. M., Flagan, R. C., and Seinfeld, J. H.: Secondary organic aerosol formation from isoprene photooxidation, Environ. Sci. Technol., 40, 1869-1877, doi:10.1021/es0524301, 2006.

Langridge, J. M., Richardson, M. S., Lack, D., Law, D., and Murphy, D. M.: Aircraft instrument for comprehensive characterization of aerosol optical properties, Part I: Wavelength-dependent optical extinction and its relative humidity dependence measured using cavity ringdown spectroscopy, Aerosol Sci. Technol., 45, 1305-1318, doi:10.1080/02786826.2011.592745, 2011.

Leibensperger, E. M., Mickley, L. J., Jacob, D. J., Chen, W.-T., Seinfeld, J. H., Nenes, A., Adams, P. J., Streets, D. G., Kumar, N., and Rind, D.: Climatic effects of 1950-2050 changes in US anthropogenic aerosols - Part 1: Aerosol trends and radiative forcing, Atmos. Chem. Phys., 12, 3333-3348, doi:10.5194/acp-12-33332012, 2012a.

Leibensperger, E. M., Mickley, L. J., Jacob, D. J., Chen, W.-T., Seinfeld, J. H., Nenes, A., Adams, P. J., Streets, D. G., Kumar, N., and Rind, D.: Climatic effects of 1950-2050 changes in US anthropogenic aerosols - Part 2: Climate response, Atmos. Chem. Phys., 12, 3349-3362, doi:10.5194/acp-12-3349-2012, 2012b.

Levy, R. C., Mattoo, S., Munchak, L. A., Remer, L. A., Sayer, A. M., Patadia, F., and Hsu, N. C.: The Collection 6 MODIS aerosol products over land and ocean, Atmos. Meas. Tech., 6, 29893034, doi:10.5194/amt-6-2989-2013, 2013.

Li, J., Ying, Q., Yi, B., and Yang, P.: Role of stabilized Criegee Intermediates in the formation of atmospheric sulfate in eastern United States, Atmos. Environ., 79, 442-447, doi:10.1016/j.atmosenv.2013.06.048, 2013.

Liao, J., Froyd, K. D., Murphy, D. M., Keutsch, F. N., Yu, G., Wennberg, P. O., St. Clair, J. M., Crounse, J. D., Wisthaler, A., Mikoviny, T., Jimenez, J. L., Campuzano-Jost, P., Day, D. A., Hu, W., Ryerson, T. B., Pollack, I. B., Peischl, J., Anderson, B. E., Ziemba, L. D., Blake, D. R., Meinardi, S., and Diskin, G.: Airborne measurements of organosulfates over the continental U. S., J. Geophys. Res., 120, 2990-3005, doi:10.1002/2014JD022378, 2015.

Liggio, J., Li, S.-M., Vlasenko, A., Stroud, C., and Makar, P.: Depression of ammoniua uptake to sulfuric acid aerosols by competing uptake of ambient organic gases, Environ. Sci. Technol., 45, 2790-2796, doi:10.1021/es103801g, 2011.

Lim, H.-J. and Turpin, B. J.: Origins of primary and secondary organic aerosol in Atlanta: results of time-resolved measurements during the Atlanta Supersite Experiment, Environ. Sci. Technol., 36, 4489-4496, doi:10.1021/es0206487, 2002.

Lin, J.-T. and McElroy, M. B.: Impacts of boundary layer mixing on pollutant vertical profiles in the lower troposphere: Implications to satellite remote sensing, Atmos. Environ., 44, 1726-739, doi:10.1016/j.atmosenv.2010.02.009, 2010.

Liu, D., Wang, Z., Liu, Z., Winker, D., and Trepte, C.: A height resolved global view of dust aerosols from the first year CALIPSO lidar measurements, J. Geophys. Res., 113, D16214, doi:10.1029/2007JD009776, 2008.

Liu, H., Jacob, D. J., Bey, I., and Yantosca, R. M.: Constraints from ${ }^{210} \mathrm{~Pb}$ and ${ }^{7} \mathrm{Be}$ on wet deposition and transport in a global three-dimensional chemical tracer model driven by assimilated meteorological fields, J. Geophys. Res., 106, 1210912128, doi:10.1029/2000JD900839, 2001.

Liu, Y., Park, R. J., Jacob, D. J., Li, Q., Kilaru, V., and Sarnat, J. A.: Mapping annual mean ground-level $\mathrm{PM}_{2.5}$ concentrations using Multiangle Imaging Spectroradiometer aerosol optical thickness over the contiguous United States, J. Geophys, Res., 109, D22206, doi:10.1029/2004JD005025, 2004.

Malm, W. C., Sisler, J. F., Huffman, D., Eldred, R. A., and Cahill, T. A.: Spatial and seasonal trends in particle concentration and optical extinction in the United States, J. Geophys. Res., 99, 13471370, doi:10.1029/93JD02916, 1994.

Mao, J., Paulot, F., Jacob, D. J., Cohen, R. C., Crounse, J. D., Wennberg, P. O., Keller, C. A., Hudman, R. C., Barkley, M. P., and Horowitz, L. W.: Ozone and organic nitrates over the eastern United States: Sensitivity to isoprene chemistry, J. Geophys. Res.-Atmos., 118, 11256-11268, doi:10.1002/jgrd.50817, 2013.

Marais, E. A., Jacob, D. J., Zhu, L., Kim, P. S., Chance, K., Abad, G., Jimenez, J. L., Krechmer, J., Hu, W. W., Campuzano-Jost, P., Fried, A., Kroll, J., Froyd, K. D., Liao, J., and McNeill, V. F.: A mechanistic model of isoprene aerosol formation for improved understanding of organic aerosol composition, presented at the SEAC ${ }^{4}$ RS Science Team Meeting, 28 April-1 May, Pasadena, Calif., 2015.

Martin, R. V., Jacob, D. J., Yantosca, R. M., Chin, M., and Ginoux, P.: Global and regional decreases in tropospheric oxidants from 
photochemical effects of aerosols, J. Geophys. Res., 108, 4097, doi:10.1029/2002JD002622, 2003.

Martin, S. T., Hung, H.-M., Park, R. J., Jacob, D. J., Spurr, R. J. D., Chance, K. V., and Chin, M.: Effects of the physical state of tropospheric ammonium-sulfate-nitrate particles on global aerosol direct radiative forcing, Atmos. Chem. Phys., 4, 183214, doi:10.5194/acp-4-183-2004, 2004.

Mauldin III, R. L., Berndt, T., Sipila, M., Paasonen, P., Petaja, T., Kim, S., Kurten, T., Stratmann, F., Kerminen, V.-M., and Kulmala, M.: A new atmospherically relevant oxidant of sulphur dioxide, Nature, 488, 193-196, doi:10.1038/nature11278, 2012.

McKeen, S., Chung, S. H., Wilczak, J. Grell, G., Djalalova, I., Peckham, S., Gong, W., Bouchet, V., Moffet, R., Tang, Y., Carmichael, G. R., Mathur, R., and Yu, S.: Evaluation of several $\mathrm{PM}_{2.5}$ forecast models using data collected during the ICARTT/NEAQS 2004 field study, J. Geophys. Res., 112, D10S20, doi:10.1029/2006JD007608, 2007.

McNeill, V. F., Woo, J. L., Kim, D. D., Schwier, A. N., Wannell, N. J., Sumner, A. J., and Barakat, J. M.: Aqueous-phase secondary organic aerosol and organosulfate formation in atmospheric aerosols: a modeling study, Environ. Sci. Technol., 46, 8075-8081, doi:10.1021/es3002986, 2012.

Millet, D. B., Baasandorj, M., Farmer, D. K., Thornton, J. A., Baumann, K., Brophy, P., Chaliyakunnel, S., de Gouw, J. A., Graus, M., Hu, L., Koss, A., Lee, B. H., Lopez-Hilfiker, F. D., Neuman, J. A., Paulot, F., Peischl, J., Pollack, I. B., Ryerson, T. B., Warneke, C., Williams, B. J., and Xu, J.: A large and ubiquitous source of atmospheric formic acid, Atmos. Chem. Phys., 15, 6283-6304, doi:10.5194/acp-15-6283-2015, 2015.

Murphy, B. N., Donahue, N. M., Fountoukis, C., Dall'Osto, M., O'Dowd, C., Kiendler-Scharr, A., and Pandis, S. N.: Functionalization and fragmentation during ambient organic aerosol aging: application of the 2-D volatility basis set to field studies, Atmos. Chem. Phys., 12, 10797-10816, doi:10.5194/acp-1210797-2012, 2012.

Murphy, D. M., Cziczo, D. J., Froyd, K. D., Hudson, P. K., Matthew, B. M., Middlebrook, A. M., Peltier, R. E., Sullivan, A., Thomson, D. S., and Weber, R. J.: Single-particle mass spectrometry of tropospheric aerosol particles, J. Geophys. Res., 111, D23S32, doi:10.1029/2006JD007340, 2006.

NADP: National Atmospheric Deposition Program Animated Maps, available at: http://nadp.sws.uiuc.edu/data/animaps.aspx, last access: 7 March 2015.

Newland, M. J., Rickard, A. R., Alam, M. S., Vereecken, L., Munoz, A., Rodenas, M., and Bloss, W. J.: Kinetics of stabilised Criegee intermediates derive from alkene ozonolysis: reactions with $\mathrm{SO}_{2}$, $\mathrm{H}_{2} \mathrm{O}$ and decomposition under boundary layer conditions, Phys. Chem. Chem. Phys., 17, 4076-4088, doi:10.1039/c4cp04186k, 2014.

Pankow, J. F.: An absorption model of gas/particle partitioning of organic compounds in the atmosphere, Atmos. Environ., 28, 185-188, doi:10.1016/1352-2310(94)90093-0, 1994.

Park, R. J., Jacob, D. J., Chin, M., and Martin, R. V.: Sources of carbonaceous aerosols over the United States and implications for natural visibility, J. Geophys. Res., 108, 4355, doi:10.1029/2002JD003190, 2003.

Park, R. J., Jacob, D. J., Field, B. D., Yantosca, R. M., and Chin, M.: Natural and transboundary pollution influences on sulfate-nitrate-ammonium aerosols in the Untied
States: Implications for policy, J. Geophys. Res., 109, D15204, doi:10.1029/2003JD004473, 2004.

Park, R. J., Jacob, D. J., Kumar, N., and Yantosca, R. M.: Regional visibility statistics in the United States: Natural and transboundary pollution influences, and implications for the Regional Haze Rule, Atmos. Environ., 40, 5405-5423, doi:10.1016/j.atmosenv.2006.04.059, 2006.

Park, R. J., Jacob, D. J., and Logan, J. A.: Fire and biofuel contributions to annual mean aerosol mass concentrations in the United States, Atmos. Environ., 41, 7389-7400, doi:10.1016/j.atmosenv.2007.05.061, 2007.

Paulot, F., Jacob, D. J., Pinder, R. W., Bash, J. O., Travis, K., and Henze, D. K.: Ammonia emissions in the Untied States, European Union, and China derived by high-resolution inversion of ammonium wet deposition data: Interpretation with a new agricultural emissions inventory (MASAGE_NH 3 ), J. Geophys. Res.-Atmos., 119, 4343-4364, doi:10.1002/2013JD021130, 2014.

Peterson, D. A., Hyer, E. J., Campbell, J. R., Fromm, M. D., Hair, J. W., Butler, C. F., and Fenn, M. A.: The 2013 Rim Fire: Implications for predicting extreme fire spread, pyroconvection, and smoke emissions, B. Am. Meteorol. Soc., 96, 229-247, doi:10.1175/BAMS-D-14-00060.1, 2015.

Pfister, L., Rosenlof, K., Ueyama, R., and Heath, N.: A meteorological overview of the SEAC ${ }^{4} \mathrm{RS}$ mission, presented at the SEAC ${ }^{4}$ RS Science Team Meeting, 28 April-1 May, Pasadena, Calif., 2015.

Pierce, J. R., Evans, M. J., Scott, C. E., D’Andrea, S. D., Farmer, D. K., Swietlicki, E., and Spracklen, D. V.: Weak global sensitivity of cloud condensation nuclei and the aerosol indirect effect to Criegee $+\mathrm{SO}_{2}$ chemistry, Atmos. Chem. Phys., 13, 3163-3176, doi:10.5194/acp-13-3163-2013, 2013.

Pye, H. O. T., Liao, H., Wu, S., Mickley, L. J., Jacob, D. J., Henze, D. K., and Seinfeld, J. H.: Effect of changes in climate and emissions on future sulfate-nitrate-ammonium aerosol levels in the United States, J. Geophys. Res., 114, D01205, doi:10.1029/2008JD010701, 2009.

Pye, H. O. T., Chan, A. W. H., Barkley, M. P., and Seinfeld, J. H.: Global modeling of organic aerosol: the importance of reactive nitrogen $\left(\mathrm{NO}_{x}\right.$ and $\left.\mathrm{NO}_{3}\right)$, Atmos. Chem. Phys., 10, 1126111276, doi:10.5194/acp-10-11261-2010, 2010.

Remer, L. A., Kaufman, Y. J., Tanre, D., Mattoo, S., Chu, D. A., Martins, J. V., Li, R.-R., Ichoku, C., Levy, R. C., Kleidman, R. G., Eck, T. F., Vermote, E., and Holben, B. N.: The MODIS aerosol algorithm, products, and validation, J. Atmos. Sci., 62, 947-973, doi:10.1175/jas3385.1, 2005.

Russell, A. R., Valin, L. C., and Cohen, R. C.: Trends in $\mathrm{OMI} \mathrm{NO}_{2}$ observations over the United States: effects of emission control technology and the economic recession, Atmos. Chem. Phys., 12, 12197-12209, doi:10.5194/acp-12-12197-2012, 2012.

Saide, P. E., Peterson, D., da Silva, A., Anderson, B., Ziemba, L. D., Diskin, G., Sachse, G., Hair, J., Butler, C., Fenn, M., Jimenez, J. L., Campuzano-Jost, P., Perring, A., Schwarz, J., Markovic, M. Z., Russell, P., Redemann, J., Shinozuka, Y., Streets, D. G., Yan, F., Dibb, J., Yokelson, R., Toon, O. B., Hyer, E., and Carmichael, G. R.: Revealing important nocturnal and day-to-day variations in fire smoke emissions through a novel multiplatform inversion, Geophys. Res. Lett., 42, 3609-3618, doi:10.1002/2015GL063737, 2015. 
Sarwar, G., Simon, H., Fahey, K., Mathur, R., Goliff, W. S., and Stockwell, W. R.: Impact of sulfur dioxide oxidation by Stabilized Criegee Intermediate on sulfate, Atmos. Environ., 85, 204 214, doi:10.1016/j.atmosenv.2013.12.013, 2014.

Saunders, S. M., Jenkin, M. E., Derwent, R. G., and Pilling, M. J.: Protocol for the development of the Master Chemical Mechanism, MCM v3 (Part A): tropospheric degradation of nonaromatic volatile organic compounds, Atmos. Chem. Phys., 3, 161-180, doi:10.5194/acp-3-161-2003, 2003.

Scarino, A. J., Obland, M. D., Fast, J. D., Burton, S. P., Ferrare, R. A., Hostetler, C. A., Berg, L. K., Lefer, B., Haman, C., Hair, J. W., Rogers, R. R., Butler, C., Cook, A. L., and Harper, D. B.: Comparison of mixed layer heights from airborne high spectral resolution lidar, ground-based measurements, and the WRFChem model during CalNex and CARES, Atmos. Chem. Phys., 14, 5547-5560, doi:10.5194/acp-14-5547-2014, 2014 a.

Scarino, A. J., Ferrare, R., Burton, S., Hostetler, C., Hair, J., Rogers, R., Berkoff, T., Collins, J., Seaman, S., Cook, A., Harper, D., Sawamura, P., Randles, C., and daSilva, A.: Assessing aerosol mixed layer heights from the NASA LaRC airborne HSRL-2 during the DISCOVER-AQ Field Campaigns: Houston 2013, Abstract A31C-3040 presented at 2014 Fall Meeting, 15-19 December, AGU, San Francisco, Calif., 2014b.

Schwarz, J. P., Perring, A. E., Markovic, M. Z., Gao, R. S., Ohata, S., Langridge, J., Law, D., McLaughlin, R., and Fahey, D. W.: Technique and theoretical approach for quantifying the hygroscopicity of black-carbon-containing aerosol using a single particle soot photometer, J. Aeros. Sci., 81, 110-126, doi:10.1016/j.jaerosci.2014.11.009, 2015.

Sipilä, M., Jokinen, T., Berndt, T., Richters, S., Makkonen, R., Donahue, N. M., Mauldin III, R. L., Kurtén, T., Paasonen, P., Sarnela, N., Ehn, M., Junninen, H., Rissanen, M. P., Thornton, J., Stratmann, F., Herrmann, H., Worsnop, D. R., Kulmala, M., Kerminen, V.-M., and Petäjä, T.: Reactivity of stabilized Criegee intermediates (sCIs) from isoprene and monoterpene ozonolysis toward $\mathrm{SO}_{2}$ and organic acids, Atmos. Chem. Phys., 14, 12143 12153, doi:10.5194/acp-14-12143-2014, 2014.

Solomon, P. A., Crumpler, D., Flanagan, J. B., Jayanty, R. K. M., Rickman, E. E., and McDade C. E.: U.S. National PM 2.5 Chemical Speciation Monitoring Networks - CSN and IMPROVE: Description of Networks, J. Air Waste Manage., 64, 1410-1438, doi:10.1080/10962247.2014.956904, 2014.

Spracklen, D. V., Jimenez, J. L., Carslaw, K. S., Worsnop, D. R., Evans, M. J., Mann, G. W., Zhang, Q., Canagaratna, M. R., Allan, J., Coe, H., McFiggans, G., Rap, A., and Forster, P.: Aerosol mass spectrometer constraint on the global secondary organic aerosol budget, Atmos. Chem. Phys., 11, 12109-12136, doi:10.5194/acp-11-12109-2011, 2011.

St. Clair, J. M., McCabe, D. C., Crounse, J. D., Steiner, U., and Wennberg, P. O.: Chemical ionization tandem mass spectrometer for the in situ measurement of methyl hydrogen peroxide, Rev. Sci. Instrum., 81, 094102-094106, doi:10.1063/1.3480552, 2010.

Stone, D., Blitz, M. Daubney, L., Howes, N. U., and Seakins, P.: Kinetics of $\mathrm{CH}_{2} \mathrm{OO}$ reactions with $\mathrm{SO}_{2}, \mathrm{NO}_{2}, \mathrm{NO}, \mathrm{H}_{2} \mathrm{O}$, and $\mathrm{CH}_{3} \mathrm{CHO}$ as a function of pressure, Phys. Chem. Chem. Phys., 16, 1139-1149, doi:10.1039/c3cp54391a, 2014.

Surratt, J. D., Kroll, J. H., Kleindienst, T. E., Edney, E. O., Claeys, M., Sorooshian, A., Ng, N. L., Offenberg, J. H., Lewandowski,
M., Jaoui, M., Flagan, R. C., and Seinfeld, J. H.: Evidence for organosulfates in secondary organic aerosol, Environ. Sci. Technol., 41, 517-527, doi:10.1021/es062081q, 2007.

Theil, H.: A rank-invariant method of linear and polynomial regression analysis, Proc. Kon. Ned. Akad. V. Wetensch. A, 53, 386392, 1950 .

Thomson, D. S., Schein, M. E., and Murphy, D. M.: Particle analysis by laser mass spectrometry WB-57F instrument overview, Aerosol Sci. Tech., 33, 153-169, doi:10.1080/027868200410903, 2000.

Thornhill, K. L., Chen, G., Dibb, J., Jordan, C. E., Omar, A., Winstead, E. L., Schuster, G., Clarke, A., McNaughton, C., Scheur, E., Blake, D., Sachse, G., Huey, L. G., Singh, H. B., and Anderson, B. E.: The impact of local sources and longrange transport on aerosol properties over the northeast U.S. region during INTEX-NA, J. Geophys. Res., 113, D08201, doi:10.1029/2007JD008666, 2008.

Toon, O. B., et al.: Planning, implementation, and scientific goals of the Studies of Emissions and Atmospheric Composition, Clouds, and Climate Coupling by Regional Surveys (SEAC ${ }^{4} \mathrm{RS}$ ) field mission, in preparation, 2015.

Travis, K., Jacob, D. J., Wennberg, P., Crounse, J., Thompson, A., Hanisco, T., Ryerson, T., Dibb, J., Huey, G., Kim, P. S., Fisher, J., Zhu, L., Marais, E., Miller, C., Yu, K., Neuman, A., Zhao, X., Yantosca, B., and Payer, M.: Declining $\mathrm{NO}_{x}$ in the Southeast US and implications for ozone- $\mathrm{NO}_{x}$-VOC chemistry, presented at the SEAC ${ }^{4}$ RS Science Team Meeting, 28 April-1 May, Pasadena, Calif., 2015.

Tsigaridis, K., Daskalakis, N., Kanakidou, M., Adams, P. J., Artaxo, P., Bahadur, R., Balkanski, Y., Bauer, S. E., Bellouin, N., Benedetti, A., Bergman, T., Berntsen, T. K., Beukes, J. P., Bian, H., Carslaw, K. S., Chin, M., Curci, G., Diehl, T., Easter, R. C., Ghan, S. J., Gong, S. L., Hodzic, A., Hoyle, C. R., Iversen, T., Jathar, S., Jimenez, J. L., Kaiser, J. W., Kirkevåg, A., Koch, D., Kokkola, H., Lee, Y. H, Lin, G., Liu, X., Luo, G., Ma, X., Mann, G. W., Mihalopoulos, N., Morcrette, J.-J., Müller, J.-F., Myhre, G., Myriokefalitakis, S., Ng, N. L., O’Donnell, D., Penner, J. E., Pozzoli, L., Pringle, K. J., Russell, L. M., Schulz, M., Sciare, J., Seland, Ø., Shindell, D. T., Sillman, S., Skeie, R. B., Spracklen, D., Stavrakou, T., Steenrod, S. D., Takemura, T., Tiitta, P., Tilmes, S., Tost, H., van Noije, T., van Zyl, P. G., von Salzen, K., Yu, F., Wang, Z., Wang, Z., Zaveri, R. A., Zhang, H., Zhang, K., Zhang, Q., and Zhang, X.: The AeroCom evaluation and intercomparison of organic aerosol in global models, Atmos. Chem. Phys., 14, 10845-10895, doi:10.5194/acp-1410845-2014, 2014.

Turquety, S., Logan, J. A., Jacob, D. J., Hudman, R. C., Leung, F. Y., Heald, C. L., Yantosca, R. M., Wu, S., Emmons, L. K., Edwards, D. P., and Sachse, G.: Inventory of boreal fire emissions for North America in 2004: the importance of peat burning and pyro-convective injections, J. Geophys. Res., 112, D12S03, doi:10.1029/2006JD007281, 2007.

US EPA: Particulate matter $\left(\mathrm{PM}_{2.5}\right)$ speciation guidance, Final draft, Edn. 1, 7 October, US Environmental Protection Agency, Monitoring and Quality Assurance Group, Emissions, Monitoring, and Analysis Division, Office of Air Quality Planning and Standards, Research Triangle Park, NC, available at: http://www3.epa.gov/ttn/amtic/files/ambient/pm25/spec/ specfinl.pdf (last access: 26 June 2015), 1999. 
van Donkelaar, A., Martin, R. V., Brauer, M., Kahn, R., Levy, R., Verduzco, C., and Villeneuve, P. J.: Global estimates of ambient fine particulate matter concentrations from satellite-based aerosol optical depth: development and application, Environ. Health Persp., 118, 847-855, doi:10.1289/ehp.0901623, 2010.

van Donkelaar, A., Martin, R. V., Pasch, A. N., Szykman, J. J., Zhang, L., Wang, Y. X., and Chen, D.: Improving the accuracy of daily-satellite-derived ground-level fine aerosol concentration estimates for North America, Environ. Sci. Technol., 46, 1197111978, doi:10.1021/es3025319, 2012.

van Donkelaar, A., Martin, R. V., Spurr, R. J. D., Drury, E., Remer, L. A., Levy, R. C., and Wang, J.: Optimal estimation for global ground-level fine particulate matter concentrations, J. Geophys. Res.-Atmos., 118, 5621-5636, doi:10.1002/jgrd.50479, 2013.

van Donkelaar, A., Martin, R. V., Brauer, M., and Boys, B. L.: Use of satellite observations for long-term exposure assessment of global concentrations of fine particulate matter, Environ. Health Persp., 123, 135-143, doi:10.1289/ehp.1408646, 2015.

Wagner, N. L., Brock, C. A., Angevine, W. M., Beyersdorf, A., Campuzano-Jost, P., Day, D., de Gouw, J. A., Diskin, G. S., Gordon, T. D., Graus, M. G., Holloway, J. S., Huey, G., Jimenez, J. L., Lack, D. A., Liao, J., Liu, X., Markovic, M. Z., Middlebrook, A. M., Mikoviny, T., Peischl, J., Perring, A. E., Richardson, M. S., Ryerson, T. B., Schwarz, J. P., Warneke, C., Welti, A., Wisthaler, A., Ziemba, L. D., and Murphy, D. M.: In situ vertical profiles of aerosol extinction, mass, and composition over the southeast United States during SENEX and SEAC4RS: observations of a modest aerosol enhancement aloft, Atmos. Chem. Phys., 15, 7085-7102, doi:10.5194/acp-15-7085-2015, 2015.

Walker, J. M., Philip, S., Martin, R. V., and Seinfeld, J. H.: Simulation of nitrate, sulfate, and ammonium aerosols over the United States, Atmos. Chem. Phys., 12, 11213-11227, doi:10.5194/acp12-11213-2012, 2012.

Wang, J., Jacob, D. J., and Martin, S. T.: Sensitivity of sulfate direct climate forcing to the hysteresis of particle phase transitions, J. Geophys. Res., 113, D11207, doi:10.1029/2007JD009368, 2008.

Wang, Q., Jacob, D. J., Spackman, J. R., Perring, A. E., Schwarz, J. P., Moteki, N., Marais, E. A. Ge, C., Wang, J., and Barrett, S. R. H.: Global budget and radiative forcing of black carbon aerosol: Constraints from pole-to-pole (HIPPO) observations across the Pacific, J. Geophys. Res.-Atmos., 119, 195-206, doi:10.1002/2013JD020824, 2014.

Warneke, C. and the SENEX science team: Instrumentation and Measurement Strategy for the NOAA SENEX Aircraft Campaign as Part of the Southeast Atmosphere Study 2013, Atmos. Meas. Tech. Discuss., in preparation, 2015.

Weber, R. J., Sullivan, A. P., Peltier, R. E., Russell, A., Yan, B., Zheng, M., de Gouw, J., Warneke, C., Brock, C., Holloway, J. S., Atlas, E. L., and Edgerton, E.: A study of secondary organic aerosol formation in the anthropogenicinfluenced southeastern United States, J. Geophys. Res., 112, D13302, doi:10.1029/2007JD008408, 2007.

Welz, O., Savee, J. D., Osborn, D. L., Vasu, S. S., Percival, C. J., Shallcross, D. E., and Taatjes, C. A.: Direct kinetic measurements of Criegee Intermediate $\left(\mathrm{CH}_{2} \mathrm{OO}\right)$ formed by reaction of $\mathrm{CH}_{2} \mathrm{I}$ with $\mathrm{O}_{2}$, Science, 335, 204-207, doi:10.1126/science.1213229, 2012.

Wolfe, G. M., Hanisco, T. F., Arkinson, H. L., Bui, T. P., Crounse, J. D., Dean-Day, J., Goldstein, A., Guenther, A., Hall, S. R., Huey,
G., Karl, T., Kim, P. S., Liu, X., Marvin, M. R., Mikoviny, T., Misztal, P., Nguyen, T. B., Peischl, J., Pollack, I., Ryerson, T., St. Clair, J. M., Teng, A., Travis, K. R., Wennberg, P. O., Wisthaler, A., and Ullmann, K.: Airborne flux observations provide novel constraints on sources and sinks of reactive gases in the lower atmosphere, submitted, 2015.

WRAP: Western Regional Air Partnership, Development of 200004 Baseline Period and 2018 Projection Year Emission Inventories, Prepared by Air Sciences, Inc. Project No. 178-8, 2005.

Xu, L., Kollman, M. S., Song, C., Shilling, J. E., and Ng, N. L.: Effects of $\mathrm{NO}_{x}$ on the volatility of secondary organic aerosol from isoprene photooxidation, Environ. Sci. Technol., 48, 22532262, doi:10.1021/es404842g, 2014.

Yu, K., Jacob, D. J., Fisher, J., Kim, P. S., Travis, K., Zhu, L., Yantosca, B., Sulprizio, M., Ryerson, T., Wisthaler, A., Fried, A., and Wennberg, P.: Impact of grid resolution on tropospheric chemistry simulation constrained by observations from the SEAC ${ }^{4} \mathrm{RS}$ aircraft campaign, presented at the SEAC ${ }^{4} \mathrm{RS}$ Science Team Meeting, 28 April-1 May, Pasadena, Calif., 2015.

Yu, S., Dennis, R. L., Bhave, P. V., and Ender, B. K.: Primary and secondary organic aerosols over the United States: estimates on the basis of observed organic carbon (OC) and elemental carbon (EC), and air quality modeled primary OC/EC ratios, Atmos. Environ., 38, 5257-5268, doi:10.1016/j.atmosenv.2004.02.064, 2004.

Zhang, H., Hoff, R. M., and Engel-Cox, J. A.: The relation between Moderate Resolution Imaging Spectroradiometer (MODIS) aerosol optical depth and $\mathrm{PM}_{2.5}$ over the United States: a geographical comparison by U.S. Environmental Protection Agency regions, J. Air Waste Manage., 59, 1358-1369, doi:10.3155/1047-3289.59.11.1358, 2009.

Zhang, L., Gong, S., Padro, J., and Barrie, L.: A size-segregated particle dry deposition scheme for an atmospheric aerosol module, Atmos. Environ., 35, 549-560, doi:10.1016/s13522310(00)00326-5, 2001.

Zhang, L., Jacob, D. J., Knipping, E. M., Kumar, N., Munger, J. W., Carouge, C. C., van Donkelaar, A., Wang, Y. X., and Chen, D.: Nitrogen deposition to the United States: distribution, sources, and processes, Atmos. Chem. Phys., 12, 4539-4554, doi:10.5194/acp-12-4539-2012, 2012.

Zhang, Q., Jimenez, J. L., Canagaratna, M. R., Allan, J. D., Coe, H., Ulbrich, I., Alfarra, M. R., Takami, A., Middlebrook, A. M., Sun, Y. L., Dzepina, K., Dunlea, E., Docherty, K., DeCarlo, P. F., Salcedo, D., Onasch, T., Jayne, J. T., Miyoshi, T., Shimono, A., Hatakeyama, S., Takegawa, N., Kondo, Y., Schneider, J., Drewnick, F., Borrmann, S., Weimer, S., Demerjian, K., Williams, P., Bower, K., Bahreini, R., Cottrell, L., Griffin, R. J., Rautiainen, J., Sun, J. Y., Zhang, Y. M., and Worsnop, D. R.: Ubiquity and dominance of oxygenated species in organic aerosols in anthropogenically-influenced Northern Hemisphere midlatitudes, Geophys. Res. Lett., 34, L13801, doi:10.1029/2007g1029979, 2007.

Zhang, X., Liu, Z., Hecobian, A., Zheng, M., Frank, N. H., Edgerton, E. S., and Weber, R. J.: Spatial and seasonal variations of fine particle water-soluble organic carbon (WSOC) over the southeastern United States: implications for secondary organic aerosol formation, Atmos. Chem. Phys., 12, 6593-6607, doi:10.5194/acp-12-6593-2012, 2012. 
Zhu, L., Jacob, D., Mickley, L., Kim, P. S., Fisher, J., Travis, K., Yu, K., Yantosca, R., Sulprizio, M., Fried, A., Hanisco, T., Wolfe, G., Abad, G. G., Chance, K., De Smedt, I., and Yang, K.: Indirect validation of new OMI, GOME-2, and OMPS formaldehyde (HCHO) retrievals using SEAC ${ }^{4} \mathrm{RS}$ data, presented at the SEAC ${ }^{4}$ RS Science Team Meeting, 28 April-1 May, Pasadena, Calif., 2015.
Zotter, P., El-Haddad, I., Zhang, Y., Hayes, P. L., Zhang, X., Lin, Y.-H., Wacker, L., Schnelle-Kreis, J., Abbaszade, G., Zimmerman, R., Surratt, J. D., Weber, R., Jimenez, J. L., Szidat, S., Baltensperger, U., and Prevot, A. S. H.: Diurnal cycle of fossil and nonfossil carbon using radiocarbon analyses during CalNex, J. Geophys. Res.-Atmos., 119, 6818-6835, doi:10.1002/2013JD021114, 2014. 